\title{
Kızlttepe İlçesinde Bitkisel Ürün Deseninde Meydana Gelen Değişimler ve Olası Olumsuz Sonuçları
}

\author{
Changing in crop patterns and possible adverse effects in Klzlltepe districts
}

\author{
Mehmet Emin Sönmez*
}

Kilis 7 Aralık Üniversitesi, Fen Edebiyat Fakültesi, Coğrafya Bölümü, Kilis

$\ddot{O}_{z:}$ Mardin ovasının güneybatı kesiminde kalan Kızlltepe ovası, sahip olduğu verimli ve geniş topraklar sayesinde hızla nüfuslanmaktadır. Ovada 2000'li yılların başına kadar nadas yöntemiyle buğday ve arpa gibi tahıllar ile mercimek ve nohut gibi baklagiller tarımsal üretimde önemli yer kaplarken, son yillarda yer altı suyunun kullanılmaya başlanmasıyla sulamalı tarım yaygınlaşmış ve mısır ile pamuk gibi yüksek gelir getiren ürünler tarımsal üretimde ön plana çıkmıştır. Kızıltepe ovasında sulamalı tarıma geçişi ürünlerin ekim alanlarının genişleyip daralmasından, yaptığımı gözlemler ve 2000 ile 2010 yılına ait uydu görüntülerinden izlemek mümkündür. Özellikle çiftçiler ile yaptığımız mülakatlar, uydu görüntülerindeki değişim ve TÜIK'in ürünlerin ekim alanlarına ait verileri arasındaki sıkı ilişki, Landsat uydu görüntüleri ile TÜIK verilerinin güvenirliliğini de ortaya koymuştur. Bunun yanında rotasyonla ürün ekiminin yapıldığı ilçede bu sistemin başarılla uygulandı̆̆ da gözlemlenmiştir. Ancak özellikle geçmişte Harran ve Karapınar ovalarında sulamada gerekli tedbirlerin alınmamış olması ve yanlış sulama yüzünden kalsifikasyon (kireçlenme), çoraklaşma ve tuzlanma gibi önemli sorunlar belirmiştir. Bu amaçla Kızıltepe ilçesinin iklim verileri, su kapasitesi, ürünün su isteği gibi parametreler de değerlendirilmiştir. Böylece, çalışmada Kızıltepe ilçesinde sulamalı tarım vasıtasıyla ürün desenindeki değişim ortaya konulmuş, ürünler $n$ su istekleri ile iklim arasındaki ilişki değerlendirilmiş ve oluşabilecek olasi sorunlar irdelenmiştir.

Anahtar Kelimler: Klzıltepe, sulu tarım, tuzlanma, kuraklık, arazi kullanımı.

\begin{abstract}
The population of the plain Kuzltepe, which is in the southwestern part of the plain Mardin, is rapidly increasing due to the its productive and large lands. Whereas cereals such as wheat and barley and legumes such as lentils and chickpeas were covered and dominant in the plain with the fallow method till the early 2000s, in the recent years, the irrigated agriculture became widespread with the introduction of groundwater and thereby, higher-yielding products such as corn and cotton came into prominence. The transition to irrigated agriculture and expansion or restriction of product plantation lands are possible to watch with view of our observations and satellite views by the year 2000 and 2010. In particular, the close relationship between our interviews with farmers, changes in satellite images and data on TSI product plantation lands indicated that the reliability of data with the TSI and Landsat satellite images. In addition, rotation of product cultivation was successfully implemented in here. However, calcification, desertification and salinization like important issued emerged in Harran and Kayapinar plains in the past because of the not taken the measures necessary for irrigation and inappropriate irrigation techniques. For this purpose, climate date, water capacity and crop water-requirements like parameters of Kizlltepe district were evaluated as well. Thus, in the present study, changing in cropping patterns with the introduction to irrigated agriculture, the relationship between crop water-requirements and climate and potential possible problems to be emerged were evaluated and discussed in here, Kizlltepe.
\end{abstract}

Keywords: Kizlltepe, irrigated agriculture, salinisation, dryness, land use.

* İletişim: M.E. Sönmez, e-posta: eminsonmez@kilis.edu.tr 


\section{Giriş}

Yeryüzünün en yaygın ve en gerekli üretim şekli olan tarımsal faaliyetler, tarımsal topraklarla beraber yeryüzünün en önemli kaynaklarını oluşturmaktadır. Nitekim sadece gıda ürünleri değil aynı zamanda dünyadaki sanayi hammaddelerinin önemli bir bölümü de tarımsal faaliyetlerden karşılanmaktadır. Nihayetinde insanı giydiren ve doyuran da topraktır (Tümertekin ve Özgüç, 2009: 119). Özellikle hızlı nüfus artışının neden olduğu gıda ve giyecek talebi yanında, oluşan yeni ekonomik düzenin tüketimi zorunlu kılması, tarımsal faaliyetler ve bu faaliyetlerin yapıldığı tarımsal alanların önemini arttırmıştır. Dünya genelinde ve ülkemizde olduğu gibi ekip-biçmeye uygun tarımsal alanların önemli bir kısmı yerleşim, sanayi, ulaşım, turizm ve benzeri beşeri faaliyetler tarafindan işgal edilirken, büyük bir kısmı da erozyon, kuraklık, tuzlanma, kireçlenme gibi faaliyetler ile kullanılmaz hale gelmektedir. Kaldı ki doğal olarak meydana gelebilen erozyon, kuraklık, tuzlanma ve kireçlenme gibi sorunların temelinde de maalesef insan faaliyetleri yatmaktadır. Türkiye'de sulama ile tarım yapılan Güneydoğu Anadolu Bölgesi'nde Harran, Akçakale ve İç Anadolu Bölgesi'nde Karapınar gibi yarı kurak iklim şartlarının hâkim olduğu ovalarda, yanlış sulama veya sulama sonrası tedbir alınmaması yüzünden çeşitli tarımsal sorunlar meydana gelmiş ve adı geçen ovalarda toprak kaynakları büyük zarar görmüştür. Kaldı ki bu sorunların boyutu, Karapınar (Konya) çevresinde yapılan bir çalışmada da belirtildiği gibi (Yılmaz, 2010), yer altı suyu kullanımından dolayı daha da artabilmektedir. Çalışmaya konu olan Kızıltepe ilçesi verimli ve tarımsal açıdan işlenmesi kolay arazilere sahiptir. Sulama ile yapılan üretimde verim değerlerinin yüksek oluşu, buna karşılık bölgede tarımsal üretimi kısıtlayacak/düşürecek olan uygun olmayan tarımsal yöntemlerin varlığı, yer altı suyunun yoğun kullanımına karşı1ık, herhangi bir önlemin alınmamış olması ve çiftçinin bilgilendirilmemesi yörede ciddi tarımsal ve toprak verimsizliği sorunları yaratacağa benzemektedir. Nitekim beșeri faaliyetlerin bir kısmının doğal çevrede yarattığı hasarlar hemen gözlenememekte ve kısa veya uzun süre sonra ortaya çıkabilmektedir. Toprakların tuzlanması, çoraklaşma, kuraklık, erozyon ve kalsifikasyon bu sorunlar arasında yer almaktadır. Zamanla doğayı onarılamayacak hale getirebilen ve çoğu zaman afet boyutuna ulaşan bu sorunlar, tarihte birçok toplumun zamanla ekonomik güçlerini kaybetmelerine ve hatta yıkılmalarına sebep olmuştur (Tümertekin ve Özgüç, 1997; Montogomery, 2010; Lowdermilk, 2009; Gimpel, 2005; Sönmez, 2011). Özellikle sulu tarım kültürünün yeni yeni yerleştiği Kızıltepe'de çoraklaşma, tuzlanma, kalsifikasyon ve yeraltı suyu ile ilgili sorunların ortaya çıkma riski çok yüksektir. Dolayısıyla ilçede yeni olan sulamalı tarımın değerlendirilmesi, ekonomik boyutunun ortaya konulması ve sulama kaynaklı oluşabilecek sorunların önceden tartışılması bu çalışmanın içeriğini oluşturmakta ve çalışmayı da önemli kılmaktadır.

Ziraat coğrafyası çalışmalarında başarılı çalışmalar üretebilmek için çalışma alanının sınırlı tutulması da önem taşımaktadır. Özellikle tarımsal üretim ile beşeri ve doğal çevre arasındaki karşılıklı ilişkilerin değerlendirilmesi ve ortaya konulması (Doğanay, 2007: 8) amacıyla gerçekleştirilen insantoprak ilişkili çalışmalarda küçük alanlarda daha detaylı ve kesin değerlendirmeler yapmak mümkündür. Türkiye gibi kısa mesafelerde yüzey şekilleri, toprak, bitki örtüsü ve iklim koşulları değişen ülkelerde planlama amacıyla olsun olmasın genel çalışmalardan ziyade yöre ve hatta alt yöre çalışmalarının yapılması zorunludur. Kaldı ki Türkiye'de doğal çevre yanında beşeri ve ekonomik özellikler ve bunların işleyişi de kısa mesafelerde büyük değişiklikler göstermektedir. Çalışma sahasının içinde bulunduğu Güneydoğu Anadolu Bölgesi her ne kadar coğrafi özellikleri bakımından benzerlik gösterse de, detayda birçok farklılığın ortaya çıkıldığg görülmektedir. Örneğin çalışma sahasında çok kısa mesafelerde yer altı suyu seviyesi değişiklik göstermekte ya da kuzeyi birden yükselerek çalışma sahasında yağış ve sıcaklık şartlarının birden değişimine etki edebilmektedir. Dolayısıyla çalışmada mümkün olduğunca Kızıltepe ilçesine ait özelliklerin dışına çıkılmamıştır. 


\section{2.Çalışma Alanı ve Genel Fiziki Özellikleri}

Kızıltepe İlçesi, Mardin ilinin batısında yer alır. Doğusunda Mardin-Merkez, batısında Derik ve Ceylanpınar, kuzeyinde Mazıdağı ilçeleri ile idari sınırı olan Kızıltepe ilçesinin güneyinde TürkiyeSuriye siyasi sınırı yer almaktadır (Şekil 1). İlçenin büyük kısmı ovalık, düz alanlardan, çok az bir kısmı ise dağlık, yüksek kesimlerden oluşmaktadır. Toplam alanı yaklaşık $1400 \mathrm{~km}^{2}$ olan ilçede Güneydoğu Anadolu step iklimi hâkim olup, yazları kurak ve sıcak, kışları ise yer yer kar yağışlı ve soğuktur.

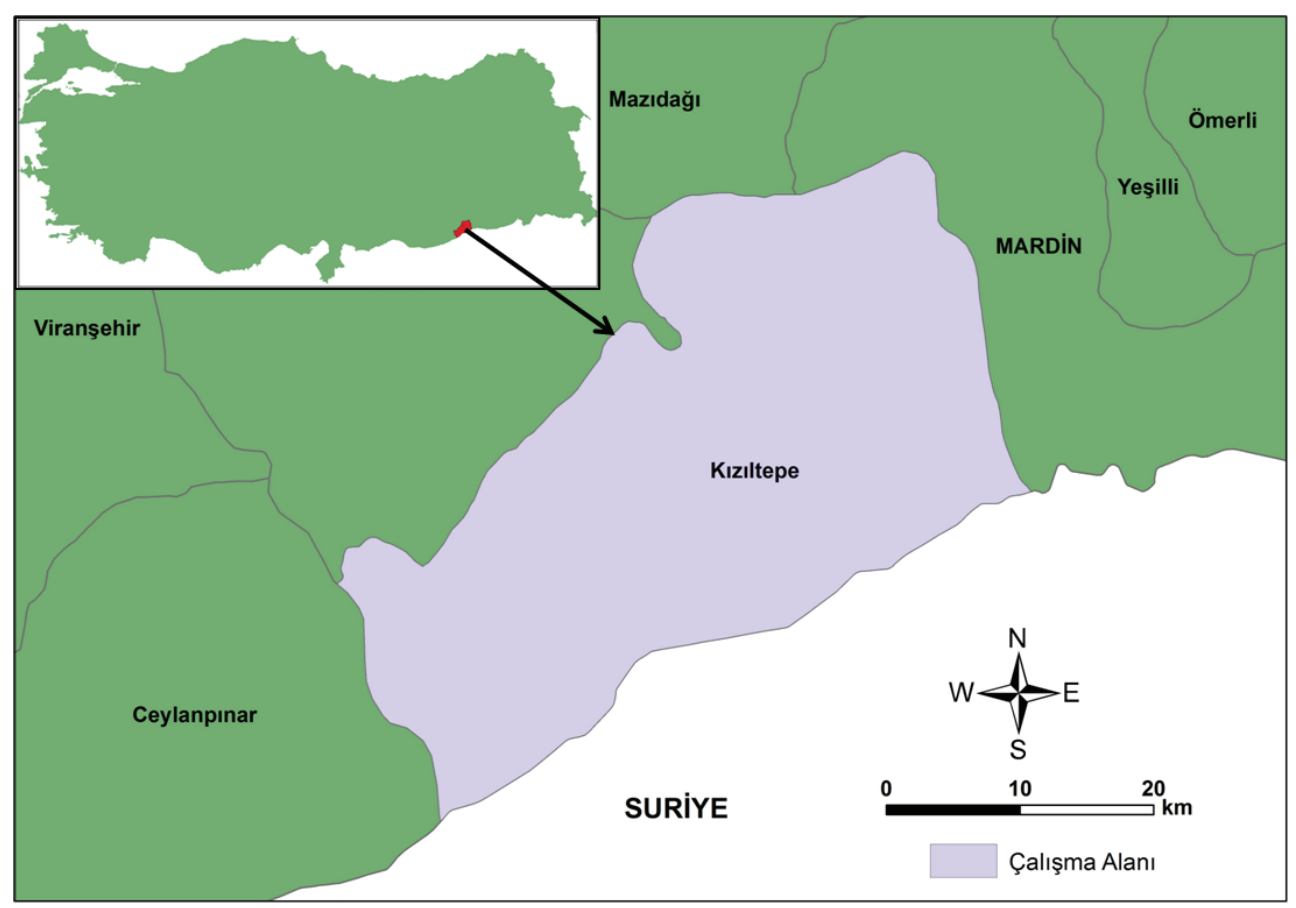

Şekil 1. Kızıltepe ilçesinin lokasyonu. 


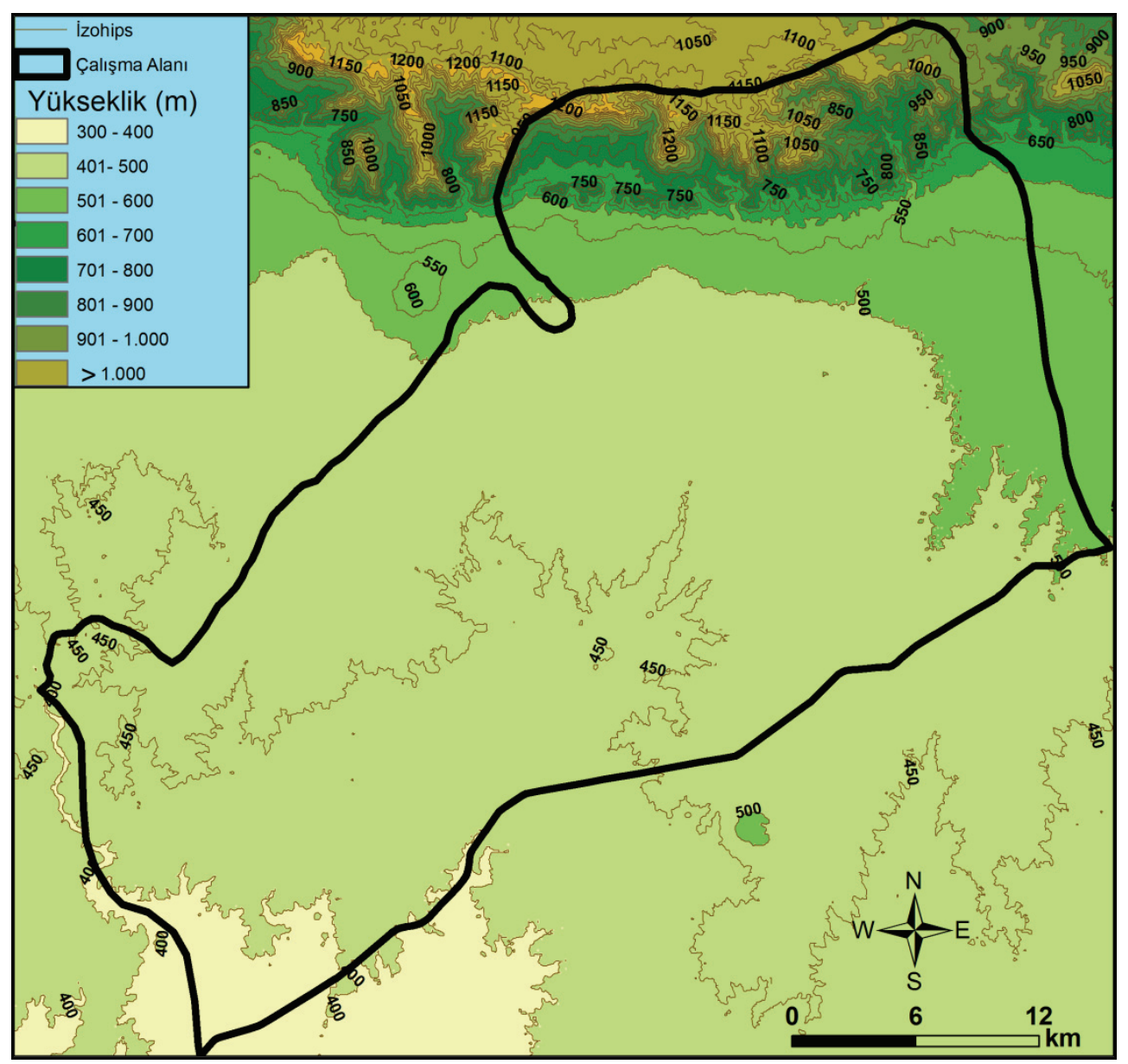

Şekil 2. Kızıltepe ilçesinin fiziki haritası.

Arazinin büyük kısmı ovalık olan Kızıltepe'de, yükselti değerleri de oldukça düşüktür. Güneybatı-kuzeydoğu doğrultulu bir ova ve kuzeyinde $1200 \mathrm{~m}$ civarlarına kadar yükselen dağl1k alandan meydana gelen ilçede, eğim değerleri de güneyden kuzeye doğru nispeten artmaktadır. Küçük ve mevsimlik akarsular tarafından yüzeysel olarak aşındırılmış olan Kızıltepe ovasında, eğim değerleri düşük, engebe yok denecek kadar azdır. Ovanın güneybatısında $400 \mathrm{~m}$ nin altında olan yükselti değerleri, kuzeydoğuya doğru artarak 500 mye ulaşmaktadır. Ovanın kuzey kesiminden doğuya doğru (Mardin) eğim düşük değerlerde artmaya devam ederken, kuzeye doğru (Mardin-Midyat Eşiği) birden dikleşir. İlçe sınırları içinde küçük bir alan kaplayan kuzeydeki bu dağlık kütle aynı zamanda ilçenin en yüksek noktalarını oluşturmaktadır. İlçe merkezi olan Kızıltepe şehir yerleşmesinin deniz seviyesinden yükseltisi ise $490 \mathrm{~m}$ dir. Kızıltepe ovasında mevsimlik akarsuların güçsüz oluşu nedeniyle akarsular, derine fazla aşındırma yapamamış, dolayısıyla ova yüzeyinde önemli sayılabilecek engebeler ve yarılmalar gelişmemiştir (Şekil 2).

Kızıltepe'de meteoroloji istasyonu bulunmadığından, ilçenin yağış, sıcaklık ve su bilançosu özelliklerine dair yorum yapabilmek amacıyla, yakın çevresinde bulunan Mardin ve Ceylanpınar istasyonlarına ait veriler kullanılmıştır. Mardin meteoroloji istasyonu Mardin-Midyat Eşiği denilen ve yaklaşık $1100 \mathrm{~m}$ yükseltideki dağlık alanda bulunurken, Ceylanpınar meteoroloji istasyonu yaklaşık 400 m yükseltideki Ceylanpınar ovasında yer almaktadır. Yükselti ve morfolojik ünitelerin yağış ve sıcaklık üzerindeki etkileri dikkate alındığında yaklaşık $450 \mathrm{~m}$ yükseltideki bir ova yüzeyinde bulunan ve aynı zamanda Ceylanpınar ovasıyla bir bütünlük oluşturan Kızıltepe'nin yağış, sıcaklık özellikleri 
ve yıllık su bilançosunun ortaya konulmasında, en yakın istasyon konumundaki Ceylanpınar meteoroloji istasyonuna ait verilerin kullanılması daha uygun görülmüştür (Tablo 1, Tablo 2).

Çizelge 1. Çalışma sahasının yakınında bulunan istasyonların aylık sıcaklık dağılışı.

\begin{tabular}{|l|l|c|c|c|c|c|c|c|c|c|c|c|c|c|c|}
\hline & Yükselti & Ocak & Şubat & Mart & Nisan & Mayıs & Haziran & Temmuz & Ağustos Eylül & Ekim & Kasım & Aralık & Yıllık Ort. \\
\hline Mardin & $1080 \mathrm{~m}$. & 3,2 & 4,1 & 8 & 13,7 & 19,7 & 25,8 & 30,1 & 29,6 & 25,3 & 18,4 & 10,7 & 5,2 & 16,2 \\
\hline Ceylanpınar & $398 \mathrm{~m}$. & 5,3 & 6,8 & 11 & 16 & 22,5 & 28,8 & 32,1 & 30,8 & 25,6 & 19 & 11,3 & 6,6 & 18 \\
\hline
\end{tabular}

Çizelge 2. Çalışma sahasının yakınında bulunan istasyonların aylık yağış dağılışı.

\begin{tabular}{|l|l|c|c|c|c|c|c|c|c|c|c|c|c|c|}
\hline & Yükselti & Ocak & Şubat & Mart & Nisan & Mayıs & Haziran & Temmuz & Ağustos & Eylül & Ekim & Kasım & Aralık & Yıllık Ort. \\
\hline Mardin & $1080 \mathrm{~m}$. & 107,2 & 122,9 & 97,0 & 79,7 & 38,5 & 6,5 & 0,6 & 0,2 & 1,9 & 37,5 & 71,2 & 112,2 & 675,4 \\
\hline Ceylanpınar & $398 \mathrm{~m}$. & 47,5 & 51,4 & 49,1 & 40,0 & 19,3 & 2,2 & 0,1 & 0,0 & 0,7 & 20,5 & 32,2 & 46,5 & 309,5 \\
\hline
\end{tabular}

Çalışma sahasına yakın bu iki istasyondan Ceylanpınar'da yıllık ortalama yağış değerleri yaklaşık $310 \mathrm{~mm}$ civarında iken, Mardin istasyonunda bu değer $675 \mathrm{~mm}$ 'ye kadar yükselmektedir. Ceylanpınar'da yıllık ortalama sıcaklık değerleri $18{ }^{\circ} \mathrm{C}$ iken, Mardin'de $16,2{ }^{\circ} \mathrm{C}$ 'dir. Ceylanpınar'daki sıcaklığın fazla, yağışın düşük oluşu ve Mardin'de tam tersi bir durumun ortaya çıkması, büyük oranda iki istasyonun yükselti değerleri arasındaki farktan kaynaklanmaktadır. Mardin $1080 \mathrm{~m}$ yükseltideki Mardin-Midyat Eşiği üzerinde bulunurken, Ceylanpınar yaklaşık 400 m yükseltide kalan ViranşehirCeylanpınar-Kızıltepe-Nusaybin ovalarının doğu-batı doğrultuda oluşturduğu düz ovalık alanda yer almaktadır. Dolayısıyla aynı morfolojik ünite üzerinde yer alan Kızıltepe $(450 \mathrm{~m})$ ve Ceylanpınar'ın (400 m) iklim özelliklerinin büyük oranda benzerlik göstermesi beklenilir. Bu nedenle Ceylanpınar meteoroloji istasyonuna ait yukarıdaki veriler Kızıltepe'nin ova kesimi için de kullanılmıştır. Buna karşılık ilçe sınırları dâhilinde kalan kuzeydeki dağlık kütleden bahsederken, Mardin meteoroloji istasyonuna ait veriler kullanılmıştır.

\section{Amaç ve Yöntem}

Yaklaşı $1100 \mathrm{~km}^{2}$ 'lik ekip-biçmeye uygun ve verimli tarımsal arazisiyle Türkiye'nin önemli ovalarından biri olan Kızıltepe, son yıllarda yeraltından sondaj yolu ile su temini sayesinde, hızla sulu tarıma geçmiş ve Kızıltepe'de ürün deseni önemli oranda değişmiştir. Ekonomik bakımdan çiftçilere önemli kazanç sağlayan sulu tarım, önceden önlem alınmadığı takdirde toprağın kullanılamaz hale gelmesine kadar birçok tarımsal sorunun ortaya çıkmasına neden olabilmektedir. Dolayısıyla bu çalışmada öncelikle Kızıltepe ilçesinde tarım ürünlerinde meydana gelen değişimin boyutu ortaya konulmuş ve ekimi yapılan bu ürünlerin su istekleri ile sulama imkânları ve iklim koşulları arasındaki ilişki değerlendirilerek olası olumsuz sonuçlar önceden kestirilmeye çalışılmıştır.

$\mathrm{Bu}$ amaçla öncelikle çalışma sahasında sulu tarımın yapıldığı alanın yıllara göre değişimi belirlenmiştir. Ürün ekim alanlarının değişimini tespit etmek için TÜİK verileri, Köyişleri Genel Müdürlüğü'nden 1984 yılına ait arazi kullanım haritası ve Landsat TM uydu görüntüleri kullanılmıştır. Bunlardan TÜİK'ten alınan veriler Excel programı ile işlenmiştir. Köyişleri Genel Müdürlüğü’nden alınan veriler ile Landsat TM uydu görüntüleri ArcGIS 10.x ortamında sayısallaştırılmıştır. Bunun yanında ilçenin tarımsal potansiyelini belirlemek amacıyla Tarım ve Köyişleri Bakanlı̆̆ı'ndan alınan ilçenin toprak tipleri, toprak derinliği, sığlığı ve eğimi ile erozyon risk durumlarını belirten haritaların ArcGIS 10 ile sayısallaştırılması yapılmıştır. Bunun yanında sıcaklık ve yağı̧̧ özellikleri ile su bilançosunu ortaya koymak amacıyla DMİ Genel Müdürlügü’nden alınan veriler kullanılmıştır. $\mathrm{Bu}$ verilerin kullanımı daha önce yapılmış çeşitli çalışmalarla da desteklenmiştir. Böylece Kızıltepe'nin toprak, yağış, sıcaklık ve su bilançosu özellikleri belirlenmiş, seçilen yeni ürünlerin su ihtiyaçlarının karşılanabilirliliği tartışılmış, yer altı suyu ile tarımsal ürünlerin ilişkileri değerlendirilmiş ve yeni tarımsal sistemin yaratacağı olası olumsuz sonuçlar ortaya konulmuştur. 


\section{Kızıltepe İlçesinin Tarımsal Potansiyeli}

Toprak ve su kaynakları insan hayatında geçmişte önemli yer tutmuş ve tutmaya da devam edecektir (Balcı Akova, 2002: 46; Doğanay, 2011: 42). Özellikle tarıma dayalı geçimin yoğun olduğu alanlarda, toprak ve su kaynakları ekonomik faaliyetlerinin tamamını biçimlendirmekte ve hayat standartlarını belirlemektedir. Kalabalık nüfusuna rağmen ekonomisi tarıma dayalı olan Kızıltepe'de, verimli topraklar, yöre halkının en önemli sermayesi durumundadır. Yerüstü su kaynaklarının yetersizliğine rağmen yeraltından sondaj ile elde edilen su miktarının yüksek oluşu (yıllık ortalama $350.000 .000 \mathrm{~m}^{3}$ ) toprakta sulama yapılmasını sağlayarak, toprakların önemini arttırmakta ve ilçe halkının refah düzeyini doğrudan veya dolaylı olarak yükseltmektedir. Kızıltepe'de tarımsal faaliyetler büyük oranda tarla tarımına dayalı olduğundan, ilçenin tarımsal potansiyelini de Türkiye genelinde olduğu gibi toprak, iklim ve su kaynakları (Özçağlar, 1988: 148) belirlemektedir. Dolayısıyla çalışmanın bu bölümünde, Kızıltepe ilçesinin büyük toprak grupları, arazi kullanım kabiliyeti, toprak derinliği-sığlığı ve eğim şartları, erozyon risk durumu ve su kaynakları ile sulama imkânları değerlendirilecektir.

Çalışma sahasındaki toprakların \% 84,4'ü kırmızımsı kahverengi topraklar, \% 9'u kahverengi orman topraklarından, \% 3'u çıplak yüzey ve yerleşme alanlarından, \% 3'ü kollüvyal topraklardan ve \%o6'sı kireçsiz kahverengi topraklarından meydana gelmektedir (Şekil 3). Çalışma sahasında, özellikle tarımın yoğun tarımsal faaliyetlerin yürütüldüğ̈̈ ova kesiminde hâkim toprak çeşidi olan Kırmızımsı Kahverengi Topraklar, ülkemizde karasal yarı kurak iklim şartlarının hüküm sürdüğü alanlarda yaygındır. Bu topraklarda kızılımsı veya kırmızımsı renk, sıcaklığın yüksekliğinden gelir. Verim değerleri yüksek olan bu topraklarda kalsifikasyona rastlanmaktadır (Atalay, 2006: 424). Kalsifikasyon (Kireçlenme), az yağış alan bölgelerde topraktaki kalsiyumun y1kanıp ortamdan uzaklaşamayışı ve alt toprakta birikmesini kapsamaktadır (Kantarcı, 2000: 312). Yağışın azlığı nedeniyle sadece toprağın üst katındaki kalsiyum karbonatın bir kısmı uzaklaşır, ancak toprağın alt katında beyaz yumrular halinde karbonat birikimi başlar (Atalay, 2006: 226). Kızıltepe gibi yarı kurak iklim şartları ve yağışın az olduğu alanlarda toprakta kireçlenme sık karşılaşılan bir süreçtir.

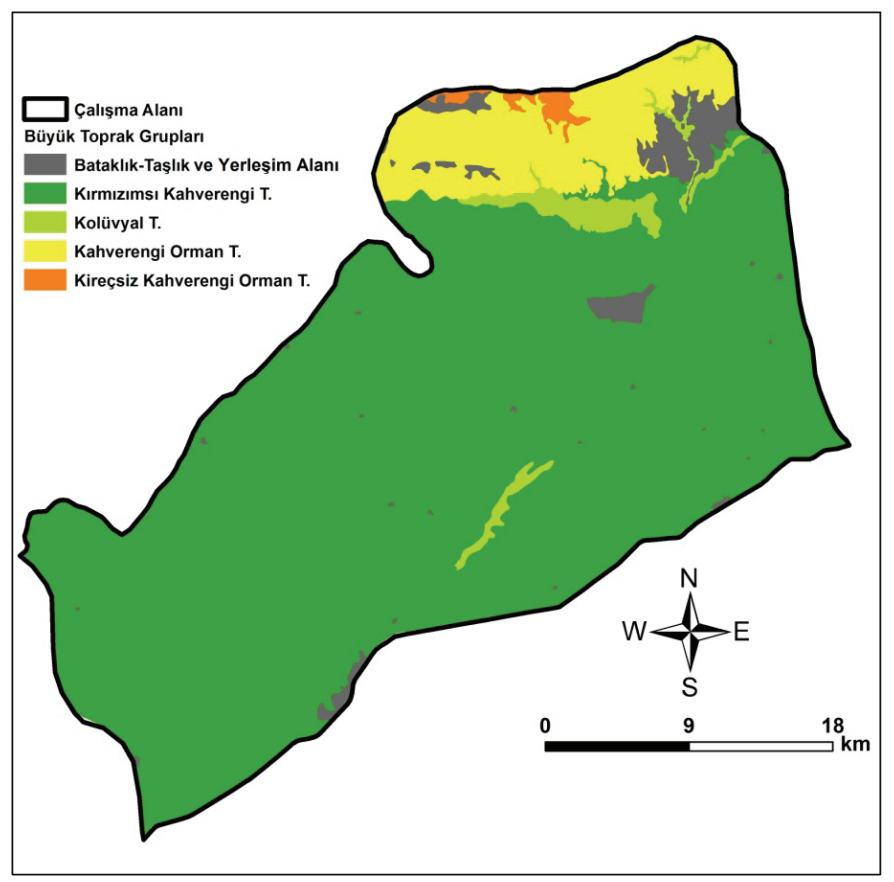

Şekil 3. Kızıltepe ilçesinin toprakları. 
Kızıltepe'nin arazi kullanım kabiliyet sınıfı haritası dikkate alındığında, çalışma sahasındaki arazilerin tarımsal açıdan değerlerinin yüksek olduğu göze çarpmaktadır. Kızıltepe'de arazinin \% 67'si I sınıf, \%13'ü II sınıf, \% 2'si III sınıf ve \%o 3'ü IV sınıf olmak üzere toplam arazinin yaklaşık \% 84'ü ekip-biçmeye uygun I-IV. sınıf arazilerden meydana gelmektedir. Geriye kalan arazinin \% 3'ü VI. sınıf, \% 11'i VII. sınıf ve \% 27'si ekip biçmeye uygun olmayan arazilerden oluşurken, ilçede yerleşim alanları ise \% 1 gibi küçük bir alan kaplamaktadır (Şekil 4). Bu veriler dikkate alındığında Kızlltepe'nin arazilerinin nerdeyse tamamının tarımsal üretime uygun olduğu ve yerleşim alanları hariç neredeyse tüm ovada tarımsal üretim yapmanın mümkün olduğu gözlenmektedir.

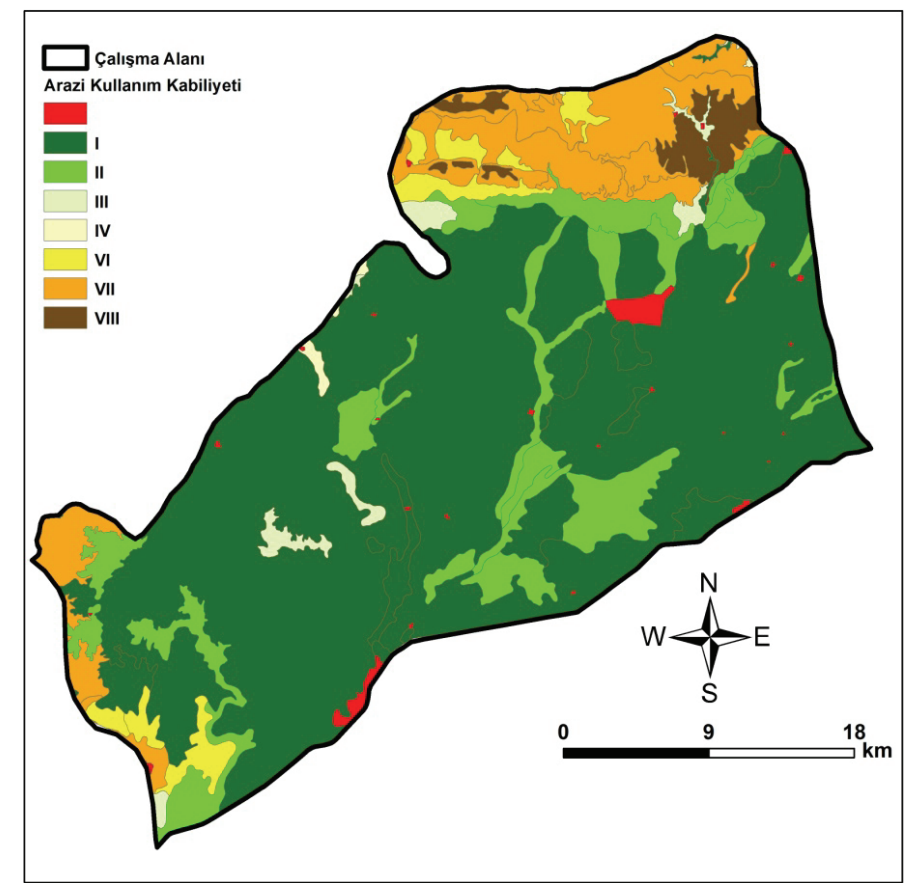

Şekil 4. Kızıltepe ilçesinde arazinin kullanım kabiliyeti.

Tarımsal üretimi kısıtlayan önemli bir parametre de erozyondur. Dolayısıyla çalışma sahasının tarımsal potansiyeli belirlenirken, arazinin erozyon risk durumu da incelenmiştir. Kızıltepe'de arazilerin erozyon risk durumlarına bakıldığında, arazilerin \% 74'ü az, \% 9'u orta, \% 6'sı şiddetli ve \% 8'i çok şiddetli erozyon riski taşıyan arazilerden oluştukları gözlenmektedir (Şekil 5). Çalışma sahasında eğimin ve yükselti değerlerinin düşük olduğu ova yüzeyinde erozyon şiddeti azdır. $\mathrm{Bu}$ durum tarımsal açıdan büyük önem taşımaktadır. Buna karşılık erozyon riski yüksek olan sahalar ise daha çok kuzeydeki dağlık kütle civarında karşımıza çıkmaktadır. Eğim değerinin yüksek olduğu bu alan, bitkisel üretim amaçlı kullanılmamakta, fakat hayvancılık faaliyetlerinde otlak olarak yararlanılmaktadır. $\mathrm{Bu}$ haritadaki veriler dikkate alındığında, Kızıltepe'de toprak erozyonu günümüzde tarımı kısıtlayan önemli bir sorun olarak karşımıza çıkmamaktadır. Fakat ovada yoğun sulamanın yapılmaya başlanması, buharlaşmanın yüksek oluşu ve fazla suları zamanında drene edecek tahliye kanallarının bulunmayışı ileride çoraklaşma ve tuzlanmaya yönelik olumsuz gelişmelerin olabileceğine işarettir. 


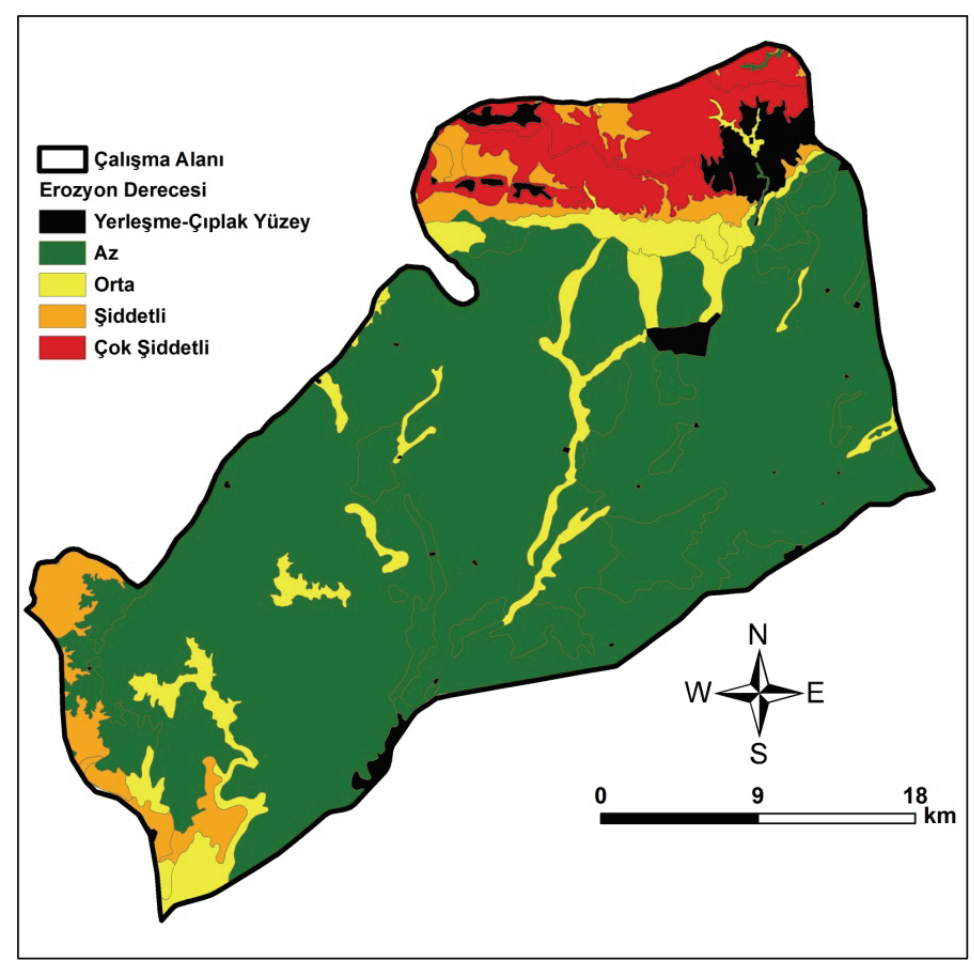

Şekil 5. Kızıltepe ilçesinde arazinin erozyon risk durumu.

Kızıltepe'de toprağın sıklığı-derinliği ve eğim değerlerinin ortak olarak gösterildiği haritada arazinin \% 77'sini (1, 2 ve 3 numara ile gösterilen alanlar) \% 0-2 eğim değerlerinde ve $90 \mathrm{~cm}$ den daha fazla derinliğe sahip topraklar oluştururken, \% 13'ünü \% 2-6 eğim değerleri arasında ve 50-90 $\mathrm{cm}$. arasında derinliğe sahip 5, 6, 7 ve 8 numaralı alanlar oluşturmaktadır. Geriye kalan arazinin yaklaşık yarısı 0-20 cm derinlikte ve \% 6-20 eğim değerlerinde araziler ile diğer yarısı çıplak, kayalık ve yerleşim alanlarından meydana gelmektedir (Şekil 6). Bu haritaya göre, Kızıltepe'de bitkisel üretim amaçlı olarak kullanılabilecek toprakların, ilçe topraklarının en az \% 80'nini oluşturduğunu söyleyebiliriz. Eğim değerlerinin düşük olduğu, toprak derinliğinin yüksek olduğu bu alanlarda erozyon riskinin de şu anda yok denecek kadar az oluşu, Kızıltepe'nin tarımsal potansiyelini büyük ölçüde yükseltmektedir. 


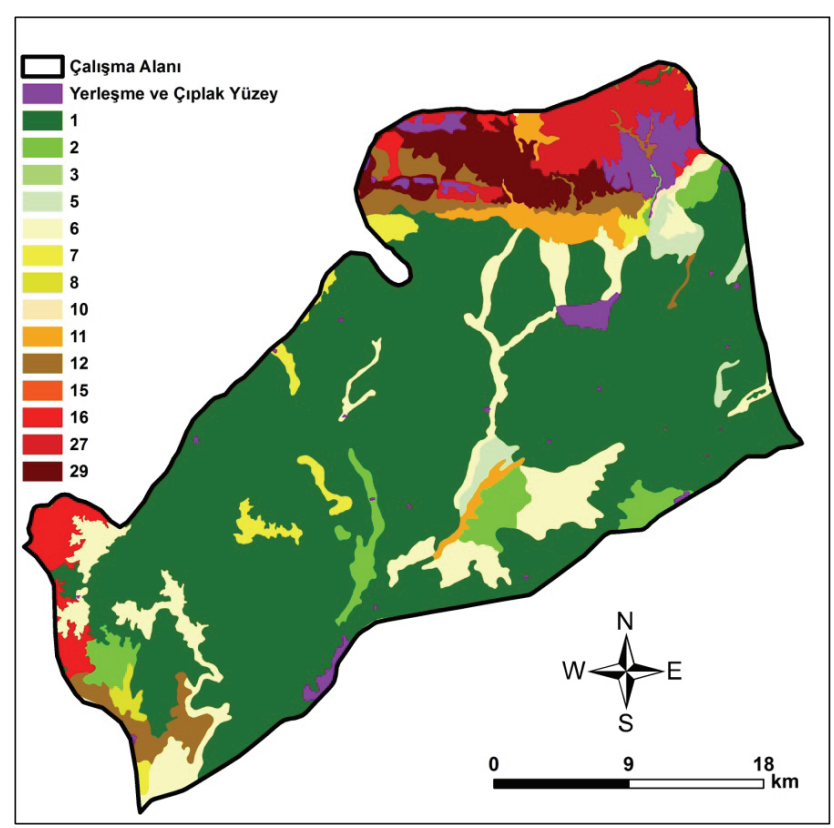

Şekil 6. Kızıltepe ilçesinde toprağın sığlığı-derinliği ve eğim özellikleri.

Çalışma sahasının eğim, toprak derinliği, toprak özellikleri, erozyon durumu ve arazinin kullanım kabiliyet sınıfları göz önüne alındığında, arazilerinin \% 85'e yakınının ekip-biçmeye uygun potansiyele sahip olduğunu söyleyebiliriz.

Bir yerin tarımsal potansiyelini belirleyen diğer önemli bir faktör ise sulama imkânları ve su kaynaklarıdır. Daimi akarsuyun bulunmadığı Kızıltepe'de, mevsimlik akarsu sayısı oldukça fazladır. Yaz kuraklığı ile beraber Mayıs ayı sonlarında tamamen kuruyan mevsimlik akarsular, sulama amaçlı kullanılamamaktadır. Özellikle yaz yağışlarının olmayışı ya da çok düşük oluşu, akarsuların tamamının mevsimlik olmasında etkili olmuştur. Dolayısıyla Kızıltepe'de tarımsal amaçlı kullanılan suyun tamamı yeraltından sondaj yolu ile elde edilmektedir. Bu nedenle Kızıltepe ilçesinde yer altı suları oldukça önemlidir. Kızıltepe ovasında yağış değerlerinin ( $309,5 \mathrm{~mm}$ civarı) düşüklüğüne karşılık, kuzeydeki Mardin-Midyat Eşiğinde yağış değerleri 675,4 mm civarlarındadır. Kalkerli yapıda olmasından dolayı Mardin-Midyat Eşiğindeki yağışların büyük kısmı süratle yer altına sızar ve dağlik kütlenin güney ve kuzey yamaçlarında kaynaklar halinde çıkar (Özçağlar, 1988: 147) ve bu alanların yer altı su seviyesine önemli katkılarda bulunur. Nitekim çalışma sahasında sondajın derinliği de buna göre farklılık göstermektedir. Kızıltepe ovasında yükselti değerleri daha düşük olmasına rağmen yaklaşık 350-360 m civarında bir derinlikten sondajla yeraltından su çekilirken, kuzeye doğru MardinMidyat Eşiği civarında 300-330 m aralığında bir derinlikteki su kullanılabilmektedir. Dolayısıyla yeraltı suyunun beslenmesinin yağış şartlarına, derinliğinin de morfolojiye bağlı olarak değiştiği gözlemlenmektedir. Böylece kuzeyde fazla yağışın etkisiyle yer altı suyu tablası yeryüzüne daha yakın yer alırken, alçakta kalan ova yüzeyinde yer altı suyu tablası daha derinlerde yer almaktadır. Bunun yanında yöredeki insanlar, 1990'larda bu değerlerin yaklaşık $50 \mathrm{~m}$ daha yükssekte olduğunu, yani 270$300 \mathrm{~m}$ derinliklerden suyun çekildiğini dile getirmişlerdir. Yeraltı su seviyesinin yıllara göre değişimi artan tarımsal amaçlı kullanım ile bağlantılı görünmektedir. İlçenin yer altı suyu rezervi tam olarak belirlenmemiş olmakla beraber, yıllık su işletme rezervinin $350.000 .000 \mathrm{~m}^{3} / \mathrm{y} 1 \mathrm{l}$ olduğu belirlenmiştir (Kırmızıtaş, 2010: 1).

\section{Tarımsal Yapıda Meydana Gelen Değişimler ve Ortaya Çıkması Olası Sorunlar}

Kızıltepe'de ekonomik faaliyetler büyük oranda tarımsal faaliyetlerin etkisi altındadır. İlçedeki nüfusun ekonomik faaliyet alanlarına dağılışı tam olarak bilinmemekle beraber, Kızıltepe'ye göre daha 
fazla sanayileşmiş Mardin ilinde bile 2000 yılı verilerine göre ancak nüfusun \% 13'üne yakın bir kısmı sanayi, ticaret ve hizmet alanlarında çalışmaktadır (TÜIK, 2011). İlçe Merkezi olan Kızıltepe Şehrinde ise nüfusun ancak \% 9'a yakını tarım dışı faaliyetlerde çalışmaktadır (TÜİK, 2000). Dolayısıyla Mardin ilinin bir ilçesi olması ve sosyo-ekonomik özellikleri bakımından Mardin iline benzerlik göstermesi nedeniyle Kızıltepe ilçesi genelinde de tarım dışı faaliyetlerde çalışan nüfus oranının Mardin iline yakın bir değerde olması muhtemeldir. Özellikle ilçedeki arazilerin büyük kısmının tarımsal amaçlı kullanılıyor olması ve bunun büyük bir kısmının mısır ve pamuk gibi gelir getiren bitkilere ayrılması ve hatta rotasyonla tarımın giderek yaygınlaşması TÜİK verilerini de desteklemektedir. Nitekim 2010 y1lı adrese dayalı kayıt sistemine göre Türkiye'de nüfusun \% 24'e yakını il ve ilçe merkezleri dışında kalan belde ve köylerde yaşarken, Kızıltepe'de bu oran Türkiye ortalamasının çok üstünde olup \% 37 civarındadır (TÜIK, 2011). Dolayısıyla çalışma sahasında tarımsal faaliyet yoğunluğunun Türkiye ortalamasının üstünde olduğu ve nüfusun büyük kısmının tarımsal faaliyetlerle geçindiğini söyleyebiliriz.

\subsection{Bitkisel Ürün Seçiminde Arazi Kullanımında Meydana Gelen Değişimler}

Yarı kurak iklim koşullarının yaşandığı ve buharlaşmanın son derece yüksek olduğu çalışma sahasında, sulama imkânlarının yaygın olmadığı 1990'lı yıllarda nadaslı ve kuru tarım yöntemleri benimsenmiştir. Bu şartlarda yetiştirilen ürünlerin başında buğday ve arpa gibi tahıllar ile mercimek ve nohut gibi bakliyatlar gelmektedir. Buğday, arpa ve mercimek günümüzde hâlâ önemli tarımsal ürünler olmakla beraber sulamalı tarımın gelişmesi ile bu ürünlerin ekim alanları büyük oranda daralmıştır. Çalışma sahasının 1984 yılına ait arazi kullanım haritası dikkate alındığında, nadas yöntemiyle yoğun kuru tarımın yapıldığı alanların ve ilçe alanının yaklaşık \% 80'nini kapladığı görülmektedir (Şekil 15). Kızıltepe'de tarımsal ürünlerin seçiminde ve arazi kullanımındaki köklü değişimlerin 2000'li yılların başında gelişmeye başladığ görülmektedir. Bu köklü değişim hem 2010 arazi kullanım haritasında hem de TÜíK'in tarımsal ürünlerin yıllara göre ekim alanlarındaki verilerin değişimiyle ortaya konabilmektedir.

Çizelge 3. Kızıltepe'deki önemli bitkisel ürünlerin ekim alanlarının (dekar) yıllara göre değişimi.

\begin{tabular}{|c|c|c|c|c|c|c|c|}
\hline & Buğday & Arpa & K. Mercimek & Nohut & Tütün & Mısır & Pamuk \\
\hline 1991 & 420.240 & 306.160 & * & * & * & * & * \\
\hline 1992 & 404.000 & 310.000 & 510.000 & 1.000 & * & $*$ & * \\
\hline 1993 & 408.060 & 310.000 & 510.200 & 1.470 & * & 20 & * \\
\hline 1994 & 400.000 & 293.250 & 500.000 & 1.500 & 600 & $*$ & 70.000 \\
\hline 1995 & 4447.760 & 269.480 & & & 15.870 & $*$ & 115.000 \\
\hline 1996 & 447.840 & 267.630 & 380.000 & 1.700 & 14.150 & 250 & 140.000 \\
\hline 1997 & 548.180 & 336.040 & 201.990 & 1.520 & 22.100 & * & 150.000 \\
\hline 1998 & 583.270 & 255.700 & 256.440 & * & 1.000 & $*$ & 192.000 \\
\hline 1999 & 572.870 & 220.470 & 264.920 & * & * & * & 194.000 \\
\hline 2000 & 555.040 & 260.000 & * & * & 260 & 10.500 & 108.450 \\
\hline 2001 & 465.990 & 308.750 & 288.070 & 2.010 & * & 25.040 & 150.000 \\
\hline 2002 & 477.820 & 274.190 & 350.760 & 970 & 170 & 12.890 & 200.000 \\
\hline 2003 & 564.650 & 252.110 & 196.390 & 980 & 690 & 59.990 & 87.850 \\
\hline 2004 & 639.780 & 191.040 & 249.700 & 800 & * & 103.800 & 128.630 \\
\hline 2005 & 594.120 & 197.340 & 300.000 & 500 & * & 141.750 & 80.000 \\
\hline 2006 & 508.865 & 149.998 & 300.000 & 200 & * & 80.863 & 169.987 \\
\hline 2007 & 614.110 & 140.000 & 250.000 & 200 & * & 185.456 & 100.000 \\
\hline 2008 & 574.583 & 89.869 & 200.000 & 200 & * & 242.518 & 142.085 \\
\hline 2009 & 652.295 & 101.804 & 140.000 & 140 & * & 202.476 & 152.492 \\
\hline 2010 & 384.051 & 70.000 & 135.329 & * & 1.256 & 226.872 & 98.000 \\
\hline
\end{tabular}

Kaynak: TUİ, 2011, Not: “*”bu döneme ait veri bulunamamıştır. 
Çalışma sahasında iklim koşulları ve sulama imkânlarının kısıtlılığı nedeniyle kuru tarım yönteminin yaygın olduğu daha önce de belirtilmişti. 2000'li yılların başlarında sulamanın yaygınlaşmaya başladığı ilçede, kuru tarım yerini giderek sulu tarıma bırakmaya başlamıştır. Kızlltepe'de, buğday, üretimi gerilemekle beraber geniş ekim alanıyla hâlâ önemini korumakta, fakat arpa, mercimek ve nohut gibi ürünlerin ekim alanı hızla daralmaktadır. Buğdayın Kızıltepe'de önemli tarımsal ürünlerden biri olmasında pamuk ile dönüşümlü ekilmesinin payı büyüktür. Bu durum aynı zamanda çiftçiye daha fazla gelir sağladığından buğday ekim alanı hâlâ geniş yer kaplamaktadır. Buna karşılık kuru tarım yöntemiyle üretilen diğer ürünlerin ekim alanı hızla daralmaktadır. Örneğin 1991yılında 306.160 dekar alanda ekimi yapılan arpa, 2000'li yılların başına kadar 300 bin dekarda ekilmeye devam edilmiştir. Fakat 2000'li yılların başında sulu tarıma geçişle beraber arpanın ekim alanı giderek daralmış ve 2010 yılına gelindiğinde sadece 70 bin dekarda ekimi yapılır olmuştur. Benzer durum mercimek için de geçerlidir. 1992 yılında 510 bin dekar alanıyla en fazla ekimi yapılan ürün olan mercimek, günümüze yaklaştıkça önemini kaybetmeye başlamış ve 2010 y1lında sadece 135.329 dekarlık alanda ekimi yapılmıştır. Gerçekten de Tablo 3 dikkate alındığında mercimek ve arpanın ekim alanı 20 yıl gibi bir süre zarfında yaklaşık 5 kat daralmıştır. Buna karşılık Güneydoğu Anadolu Bölgesi genelinde ve özellikle bölgedeki ovalar ve alçak platolarda olduğu gibi (Doğanay, 2011: 95) Kızıltepe'de de mısır ve pamuğun ekim alanının genişlediği göze çarpmaktadır. Kızıltepe Ovası'nda 1993 yılında ekimi yapılmayan pamuk, bu dönemden sonra yıldan yıla dalgalanma göstermekle beraber 1994 yılında 70 bin dekar, 2000 yılında 108.450 dekar, 2009 y1lında 152.492 dekar ve 2010 yılında 98 bin dekar alanda ekilmiştir. Pamuk ekim alanındaki bu dalgalanma buğday ile dönüşümlü ekim yapılmasından kaynaklanmaktadır. Pamuk ekimi yapılması düşünüldügünde arazi genelde nadasa bırakılmakta ve sonraki yıl Nisan ayının 15'inden sonra ekimi yapılmaktadır. Pamuk II. ürün olarak seçildiğinde ise ekimi Temmuz ayının başında yapılmakta fakat bu dönemde yüksek sıcaklıklar pamuğun yetişme devresine denk gelmekte ve verimi önemli ölçüde düşürmektedir. Dolayısıyla çalışma sahasında pamuk ekimi II. ürün olarak tercih edilmemektedir. 1993 yılında 20 dekarda ekimi yapılan mısır ise ekim alanı bakımından daha istikrarlı bir şekilde genişlemektedir. 1996 yılında ekim alanı sadece 250 dekar olan misır, 2000 yılında 10.500 dekar, 2005 y1lında 141.750 dekar ve 2010 yılında 226.872 dekar alanda ekilmiştir (Tablo 3). Çalışma sahasında buğdayın hâlâ geniş ekim alanına sahip olmasında rotasyonla ürün ekiminin etkisi çok büyüktür. Nitekim sonbaharda ekimi yapılan buğday Haziran ayında hasadı yapılmakta ve bu ürünün yerine yaklaşık 2 hafta sonra misir ekilmektedir. 


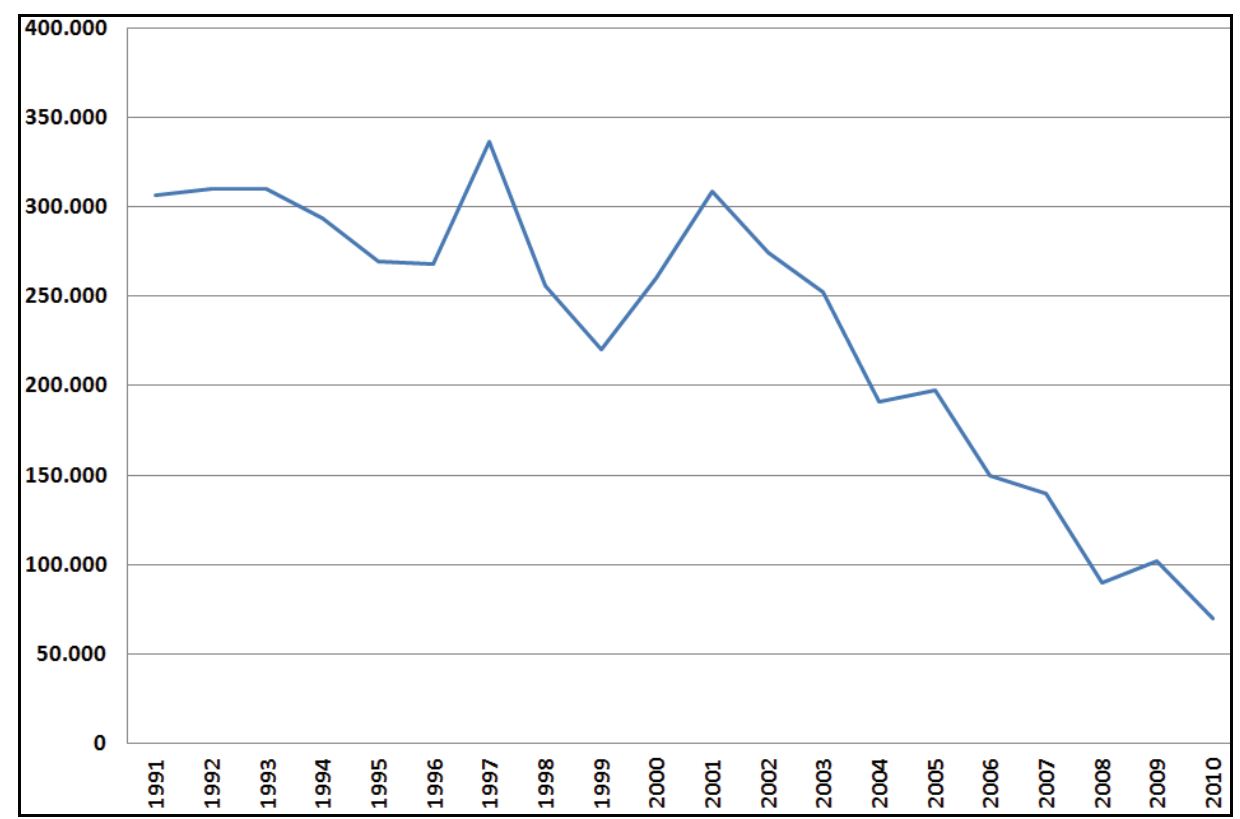

Şekil 7. Kızıltepe ilçesinde arpa ekim alanlarının yıllara göre değişimi (dekar).

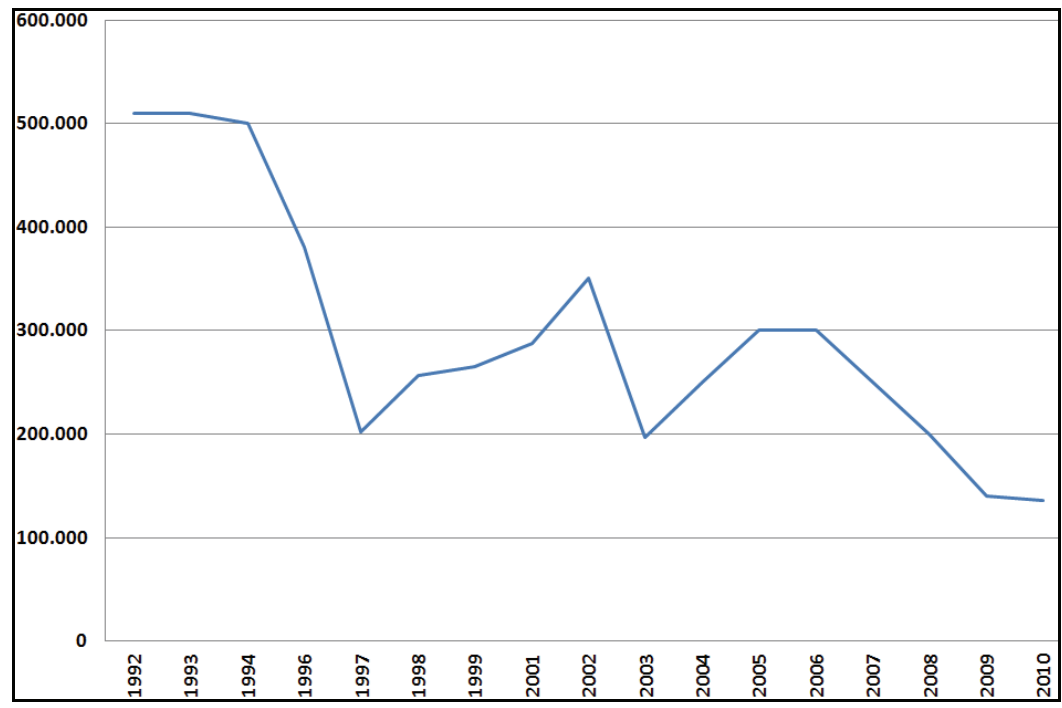

Şekil 8. Kızıltepe ilçesinde mercimek ekim alanlarının yıllara göre değişimi. 


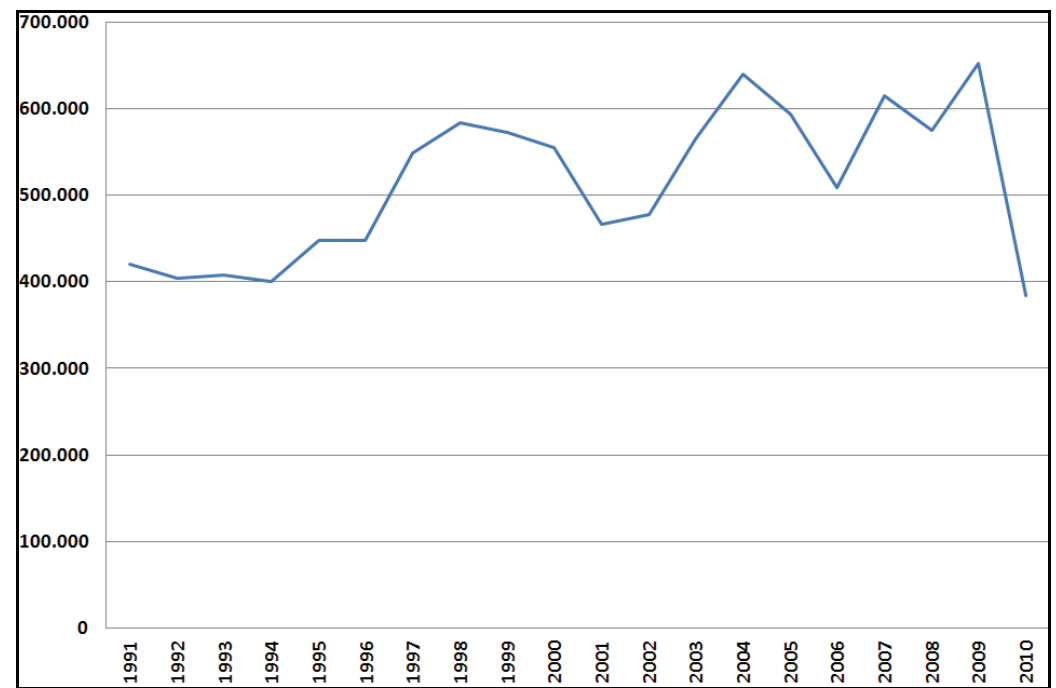

Şekil 9. Kızıltepe ilçesinde buğday ekim alanlarının yıllara göre değişimi (dekar).

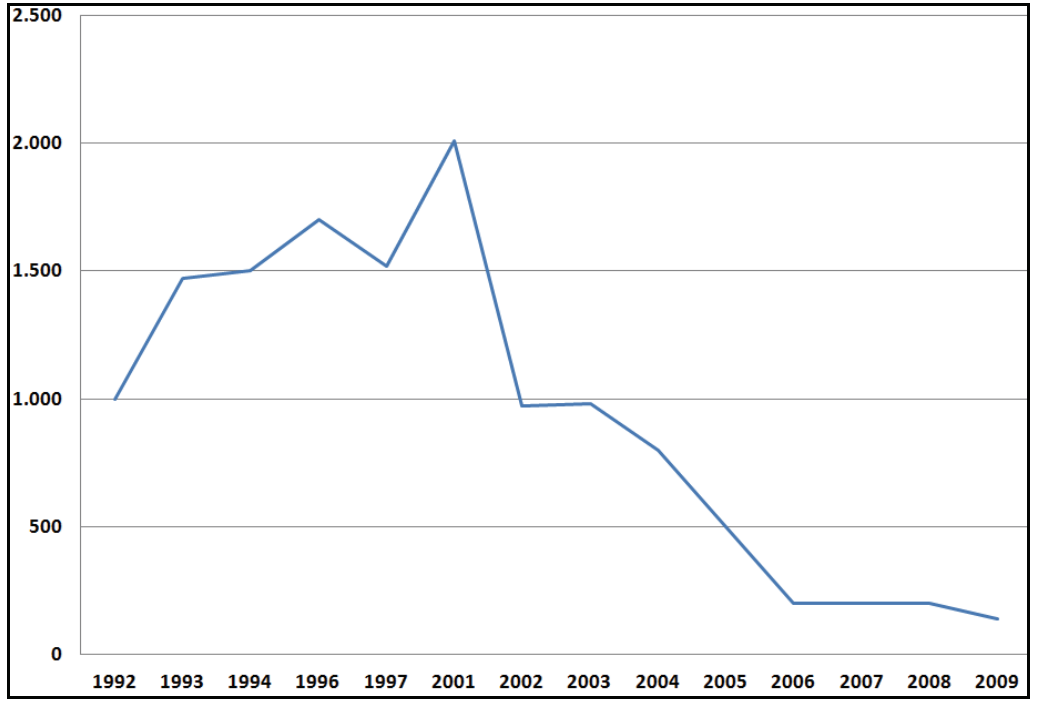

Şekil 10. Kızıltepe ilçesinde nohut ekim alanının yıllara göre değişimi (dekar). 


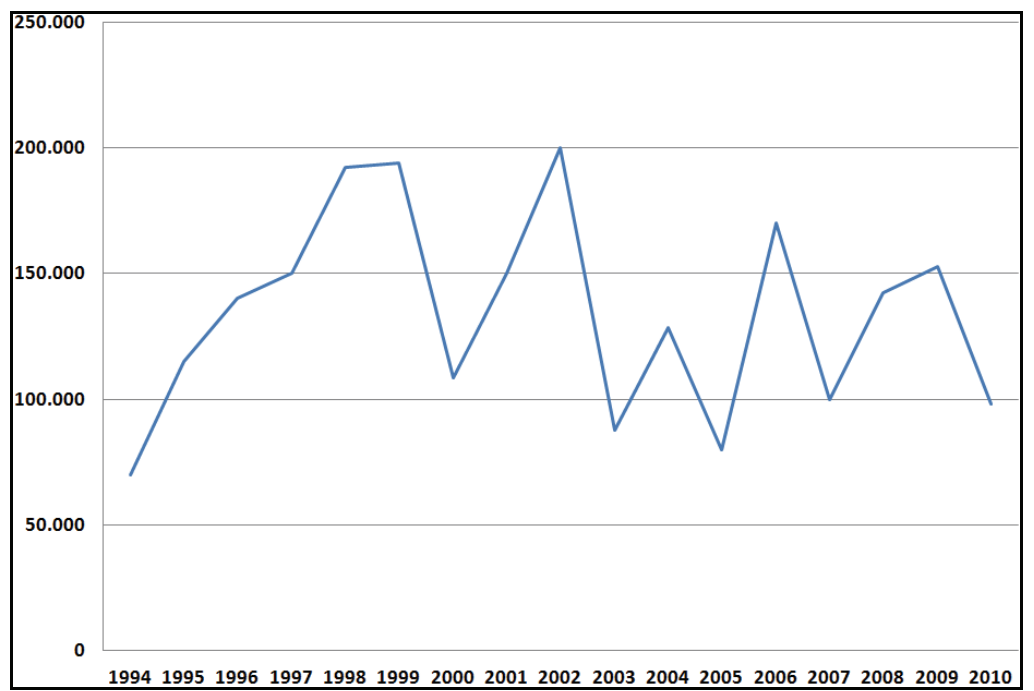

Şekil 11. Kızıltepe ilçesinde pamuk ekim alanının yıllara göre değişimi (dekar).

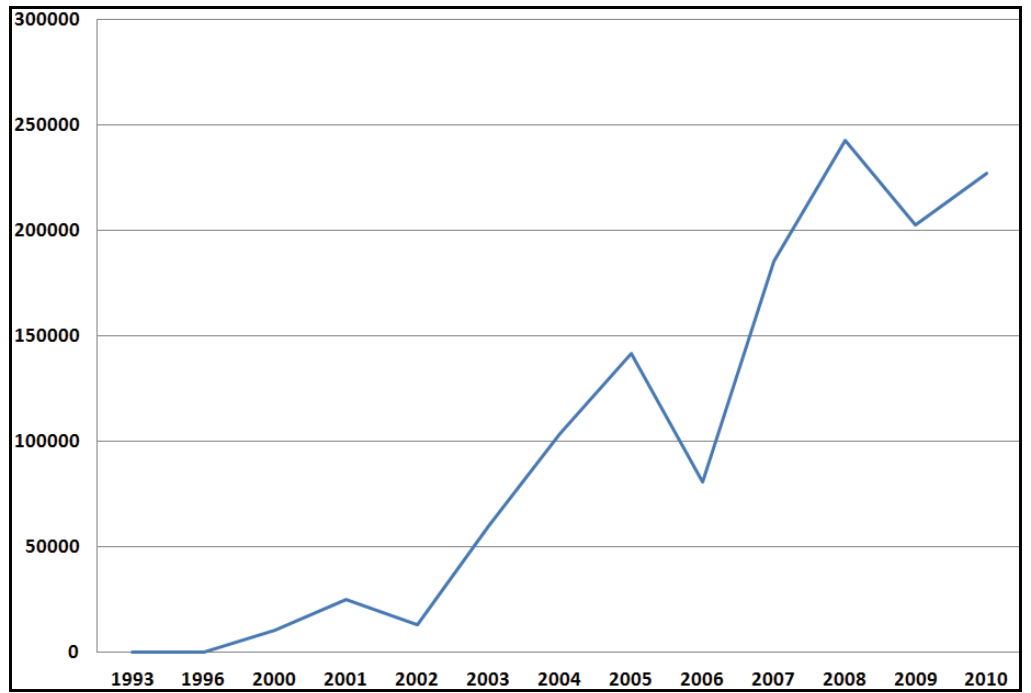

Şekil 12. Kızıltepe ilçesinde mısır ekim alanının yıllara göre değişimi (dekar). 


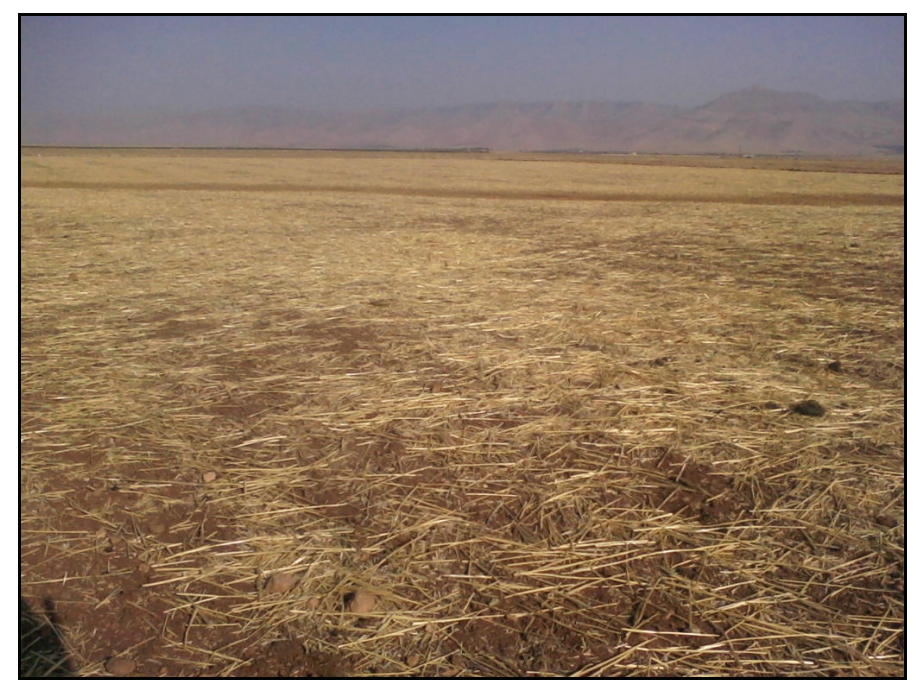

Foto 1. 28 Haziran 2011 (Buğday tarlası).

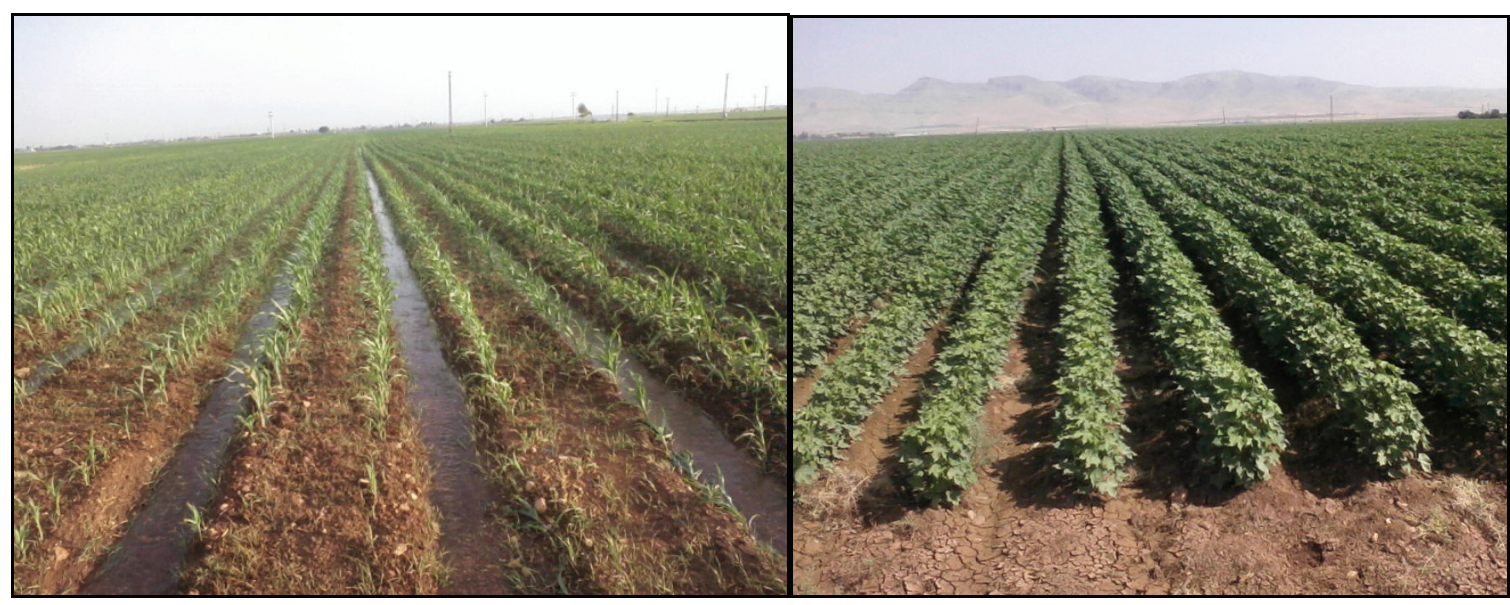

Foto 2. 25 Temmuz 2011 (sağda mısır, solda pamuk tarlası).

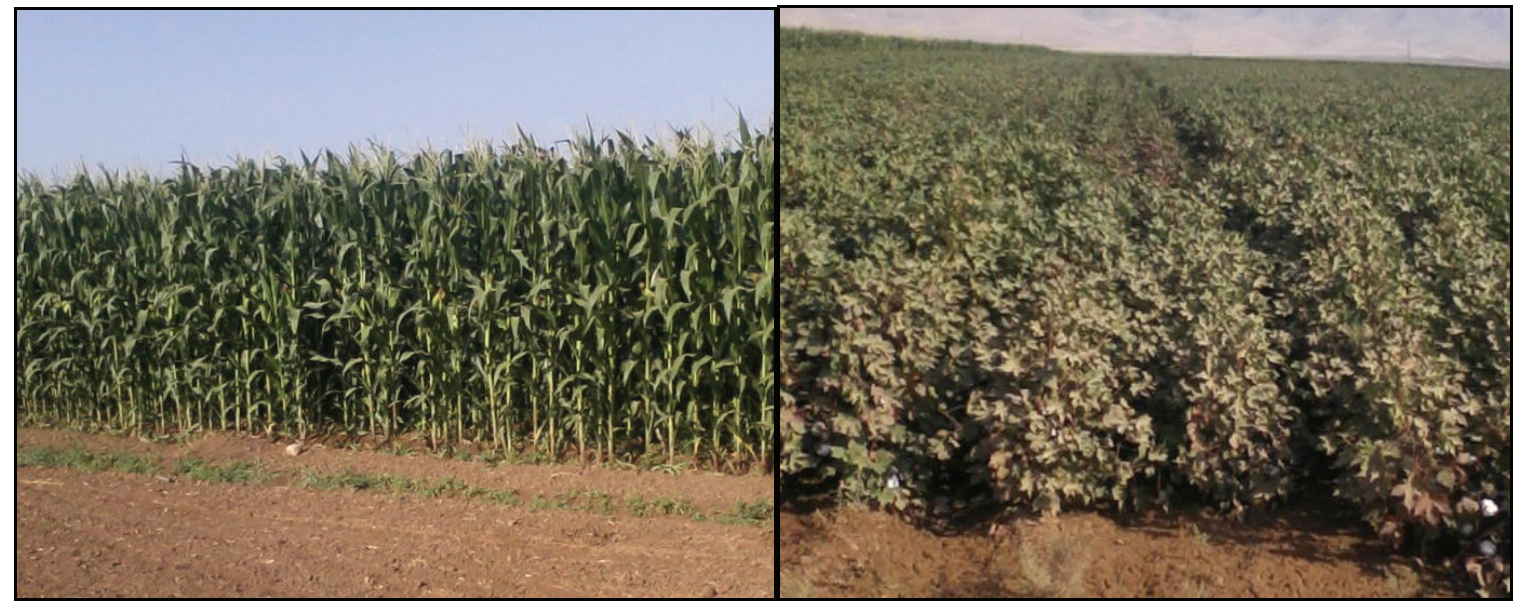

Foto 3. 28 Eylül 2011 (sağda mısır, solda pamuk tarlası). 
Çalışma sahasında mısır veriminin gün geçtikçe arttığı ve batı ülkelerindeki verimin de üstüne çıktığı görülmektedir. Günümüzde Türkiye'de mısır üretiminde ortalama verim hektar başına ortalama 5-5,5 ton arasındadır. Batılı ülkelerde 7 ton civarındadır (Doğanay, 2011: 55). Çalışma sahasında 2000 yılında hektar başına ortalama 5,5 ton civarında olan verim değerleri, 2003 yılında 6 tonun, 2004 yılında 8 tonun üzerine çıktı̆̆ı, günümüzde 8,5 ton dolayında olduğu görülmektedir (Şekil 15).

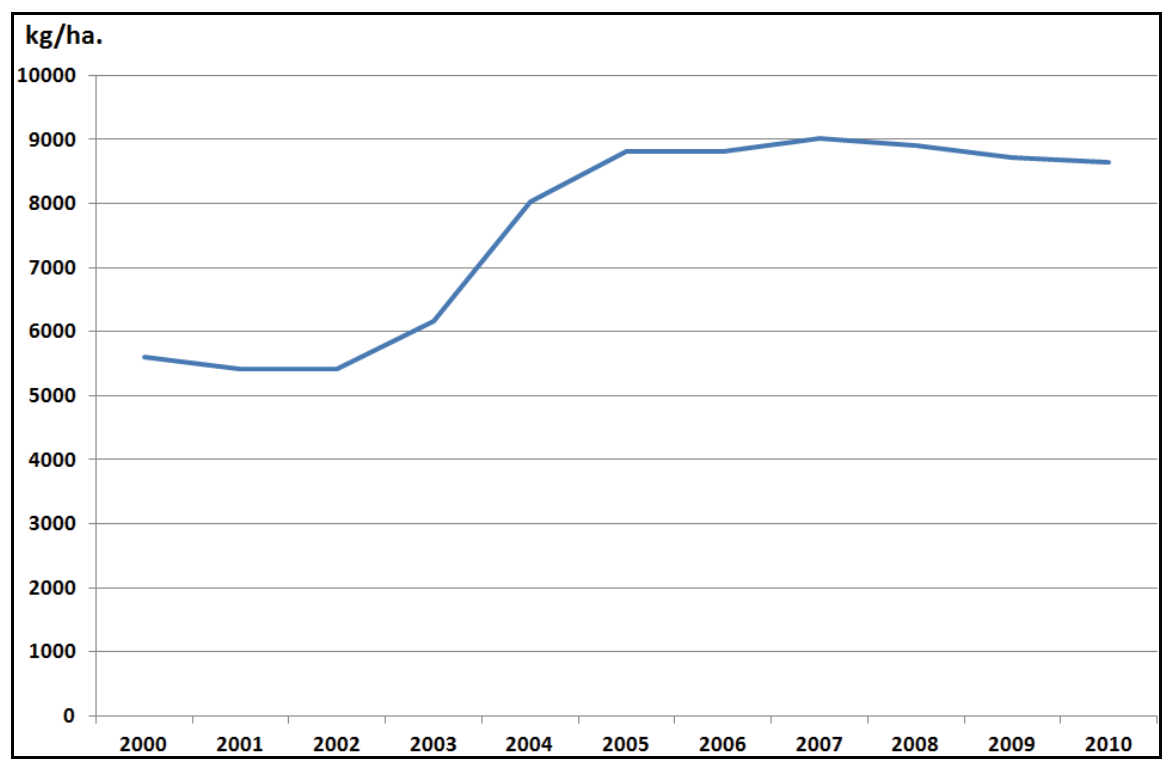

Şekil 13. Kızıltepe'de mısır üretiminde verimin yıllara göre değişimi ( $\mathrm{kg} / \mathrm{ha}$.)

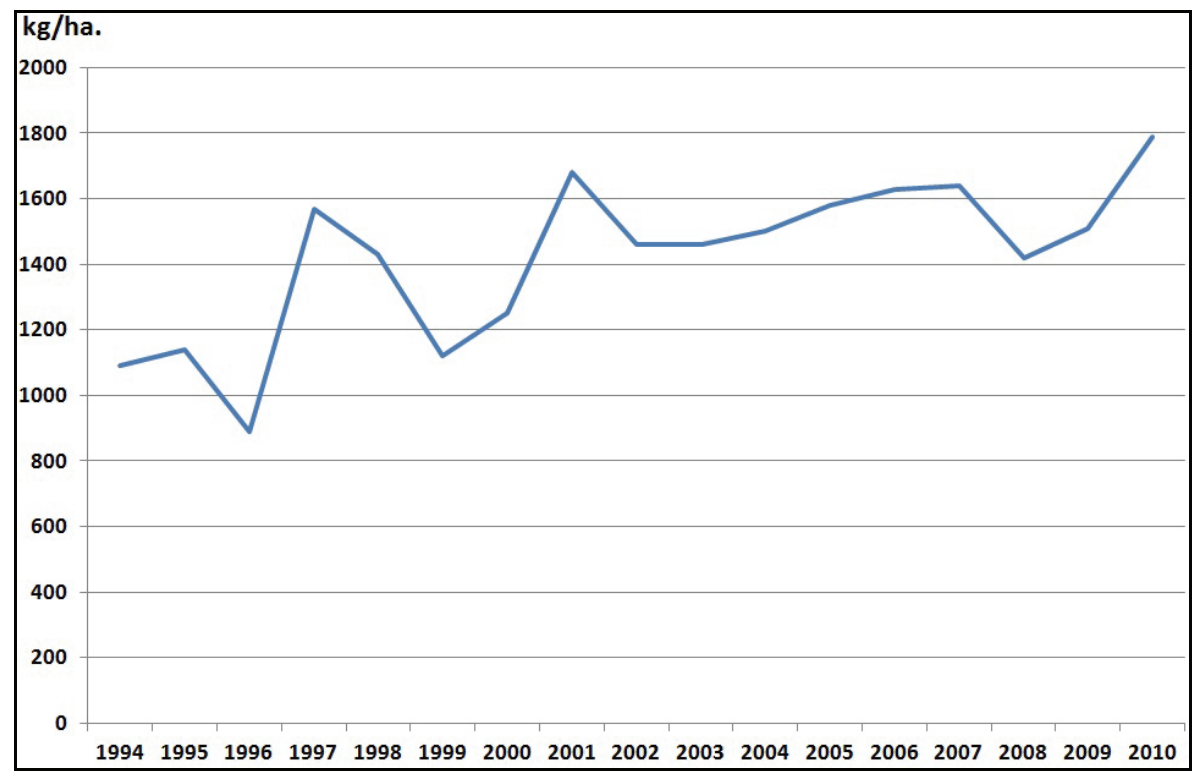

Şekil 14. Kızıltepe'de lif (saf) pamuğun verimin yıllara göre değişimi (kg/ha.)

Misır verimindeki olumlu durum pamuk üretiminde de kendini göstermektedir. Türkiye'de 2008 yılında hektar başına lif (saf) pamuk verimi ortalama 1054 kg/ha'dır (Doğanay, 2011: 97). Buna karşılık Kızıltepe'de 1994 yılında 1090 kg/ha olan lif (saf) pamuk verimi, yıllara göre değişmekle beraber hızla artarak 2000 yılından sonra sürekli $1400 \mathrm{~kg} / \mathrm{ha}$ 'ın üzerinde seyretmiştir. İlçede 2010 yılı verilerine göre hektar başına lif (saf) pamuk verim değerleri $1790 \mathrm{~kg} / \mathrm{ha}$ olarak belirlenmiştir. 
Dolayısıyla Kızıltepe hem lif (saf) pamuk hem de mısır verimi Türkiye ortalamasının oldukça üstündedir.

\subsection{Arazi Kullanımında Meydana Gelen Değişimler}

Kızıltepe ilçesinin 1984 yılında hazırlanmış arazi kullanım haritasına göre, ilçenin arazi kullanımının büyük oranda iklimin etkisi altında olduğu dikkati çekmektedir. İlçede arazinin $\% 75^{\prime} \mathrm{i}$ nadas uygulanarak, \% 6's1 ise nadasa birakmaksızın toplam arazinin \% 81'inde kuru tarım yapılmaktadır. Buharlaşmanın yüksek olması, su kaynakları ve sermayenin yetersizliği 1980 ve 90'lı yıllarda, ilçede nadas yöntemi ile tarımı zorunlu kılmıştır. 1984 yılı arazi kullanım haritasına göre sulu tarım toplam arazinin \% 3'ü gibi küçük bir kısmında yapılmaktadır. Nitekim bu da ancak mevsimlik akarsu yataklarına yakın, taban suyunun nispeten yüksek olduğu alanlarda karşımıza çıkmaktadır. 1984 yılında ormanlık alanın hiç bulunmadığı ilçede, toprakların \% 9'u mera, \% 4'ü fundalık alanlardan meydana gelirken, arazinin \% 3'ü yerleşme ve çıplak alanlardan oluşuyordu (Şekil 15).

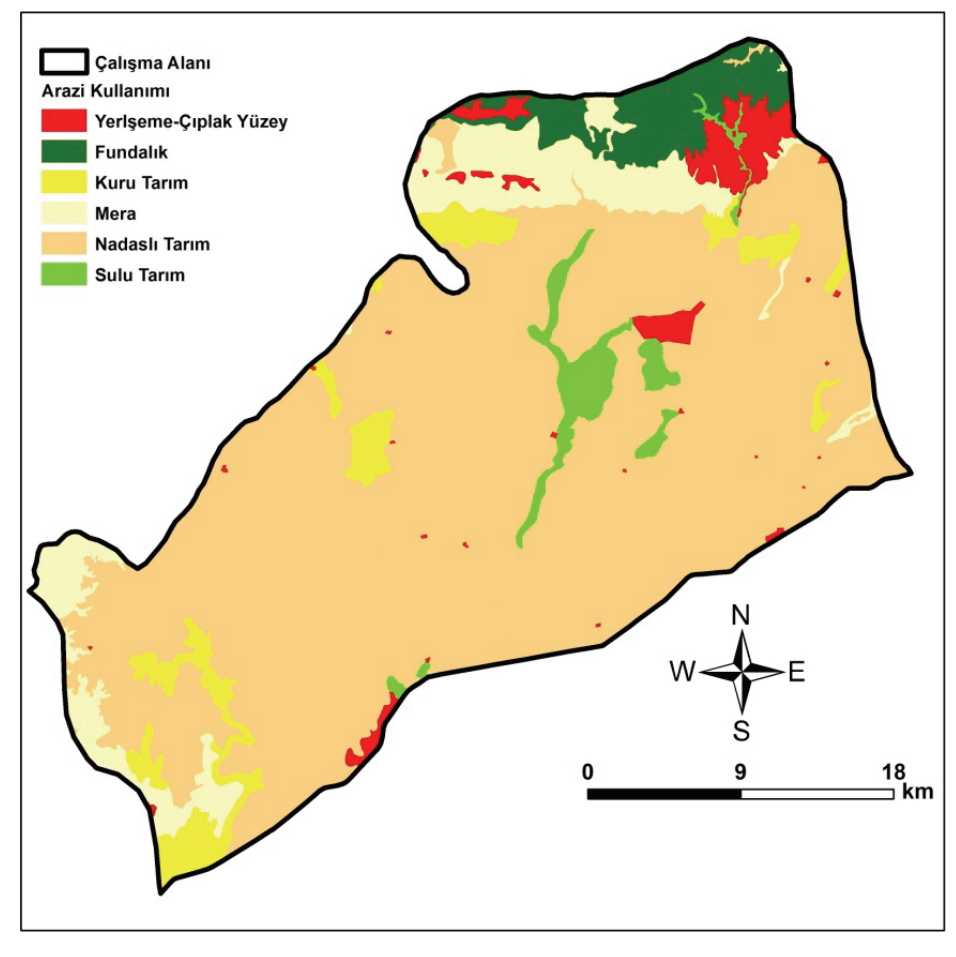

Şekil 15. Kızıltepe ilçesinde arazi kullanımı (1984 yılı).

Çalışma sahasındaki bitki desenindeki değişimi belirlemek amacıyla çalışma sahasının 2000 ve 2010 yıllarının Ağustos ayına ait uydu görüntüleri kullanılmıştır. Sulama yapılan alanları belirlemek için Güneydoğu Anadolu Bölgesi'nin ve Türkiye'nin en kurak ayı olan Ağustos ayı tercih edilmiştir. Yarı kurak iklim şartlarının hâkim olduğu Kızıltepe'de, Ağustos ayında step bitkilerinin büyük kısmı vejetatif gelişimini tamamlar ve kış durumuna geçerler. Buna karşıllk Temmuz ayı içinde ekimi yapılan mısır ve pamuk gibi ürünler ise henüz olgunlaşma aşamasında olduğundan yeşil kalmaktadır. Böylece Ağustos ayına ait uydu görüntülerinden elde edilen veriler bitki desenindeki değişimi ortaya koymak için büyük önem taşımaktadır. Çalışma sahasında GPS ile alınan noktalar ve uydu görüntülerine ait veriler çakıştırıldığında, iki verinin de birbiriyle \% 90'nın üzerinde uyumlu 
olduğu belirlenmiştir. Bunun yanında çalışma sahasında bitki deseninde meydana gelen değişimin gösterildiği 2000 ve 2010 yıllarına ait uydu görüntüleri TÜİK'ten alınan verilerin yıllara göre değişimi ile de desteklenmektedir. Dolayısıyla bu haritaların güvenirlilik derecesi çok yüksektir ve çok büyük oranda gerçeği yansıtmaktadır. Kızıltepe'nin 2000 yılı Ağustos ayına ait uydu görüntülerinden elde edilen veriler dikkate alındığında; ilçe topraklarının \% 69'nun tarım dışı sahalardan (mera ve çıplak alanlar) meydana geldiği, \% 18'nin nadaslı ve kuru tarım sahaları olduğu ve geriye kalan \% 13'ünde ise sulu tarım yapıldığı saptanmıştır. Çalışma sahasının aynı duyarlılığa sahip 2010 yılı Ağustos ayına ait uydu görüntülerinde ise arazi kullanımında önemli değişimlerin yaşandığı gözlenmektedir (Şekil 10). Buna göre, çalışma sahasında sulu tarım yapılan alan hızla büyümüş ve ilçe topraklarının \% 42'sini kaplamıştır. Sulu tarım alanlarının genişlemesine karşılık kuru tarım ve mera (çıplak alanlar) arazilerinde önemli bir azalış gerçekleşmiştir. Özellikle ova yüzeyindeki mera veya şahıslara ait tarım dışı araziler tamamen yerini sulu tarım alanlarına bırakmıştır. Böylece Kızıltepe'de tarım dışı araziler 2010 yılının Ağustos ayında ilçe topraklarının \% 46'sını, kuru ve nadaslı tarım yapılan alanlar ise ancak \% 10'nu kaplayacak kadar gerilemiştir. Tabi ki ekim yapılmayan alan olarak ifade edilen arazilerin bir kısmı kuru tarım yapılan alanların içine dâhil edilebileceği gibi, diğer bir kısmı ise kuru tarım yöntemiyle elde edilen gelirin düşüklüğü ve suyun yetersizliği nedeniyle uzun yıllar ekim yapılmayan tarım sahaları içine de koyabiliriz.

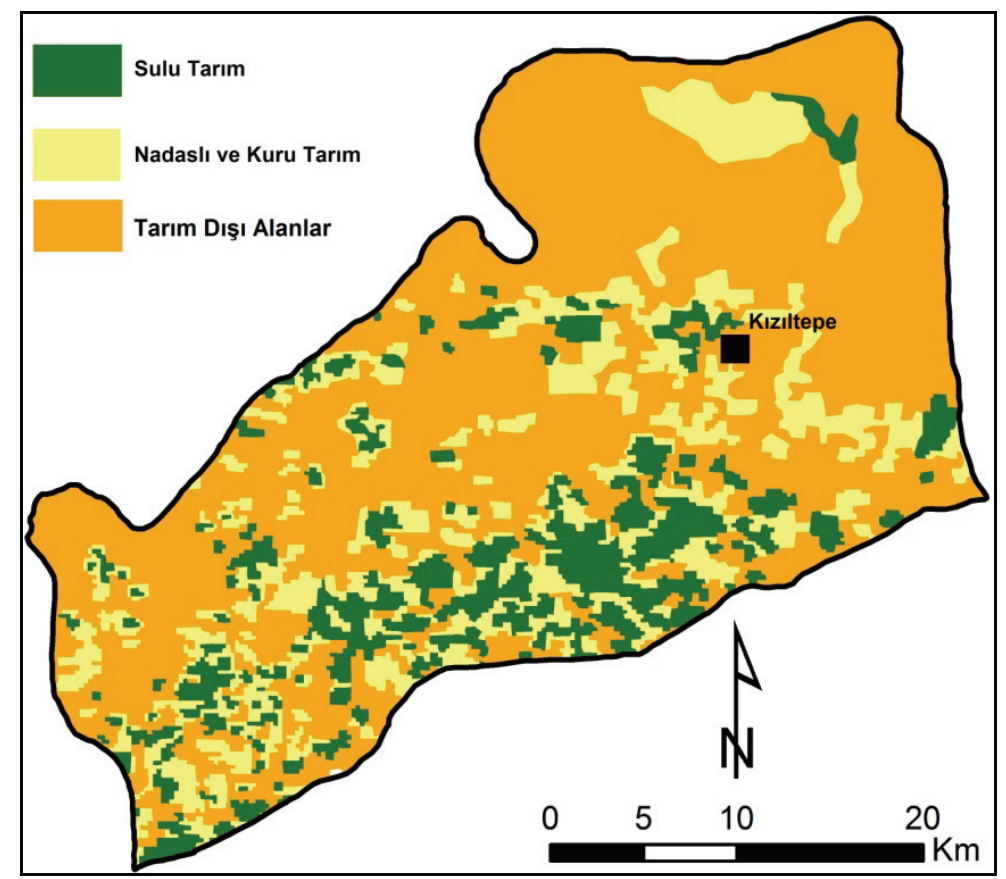

Şekil 16. Kızıltepe ilçesinde arazi kullanımı (Ağustos, 2000, Landsat TM). 


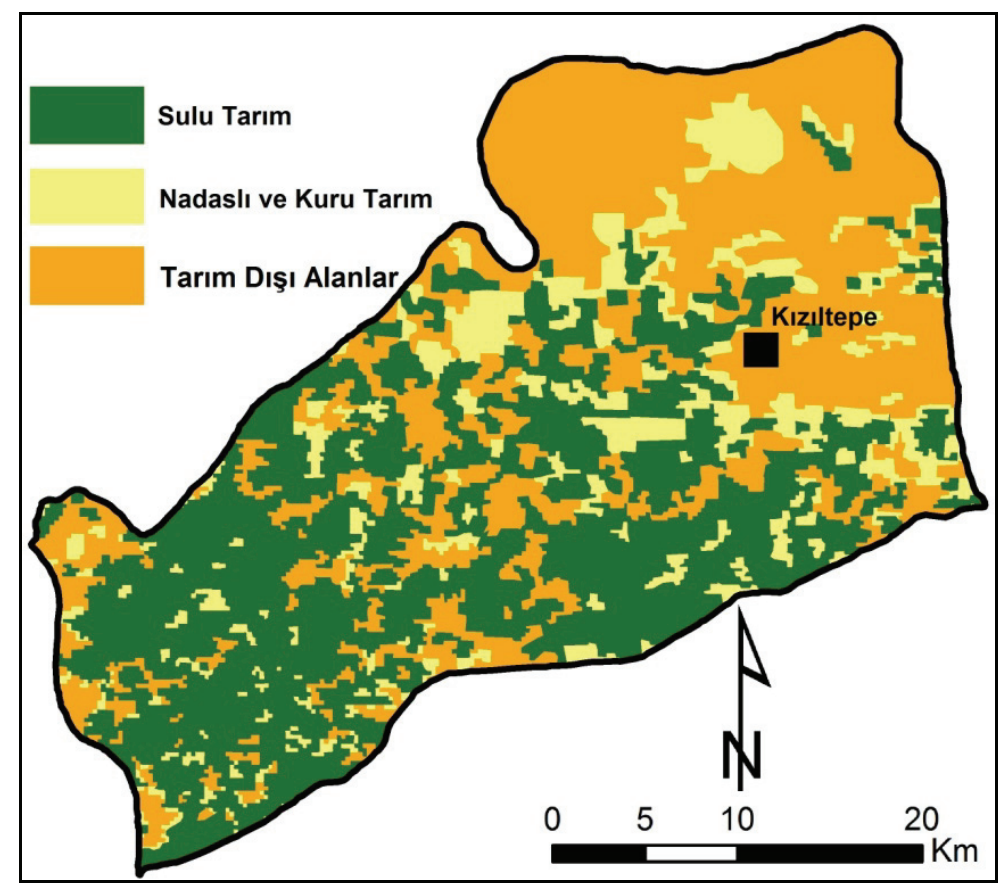

Şekil 17. Kızıltepe ilçesinde arazi kullanımı (Ağustos, 2010, Landsat TM).

\subsection{K1zıltepe'de Sulama ile Yetiştirilen Ürünlerin Su İstekleri}

Toprak ve su kaynakları ülkelerin en önemli doğal zenginlikleri arasında yer alır. Toplumların sosyo-ekonomik kalkınmalarında, söz konusu kaynakların geliştirilerek akılcı kullanımının büyük önemi bulunmaktadır. Su, canlılar için vazgeçilemez bir doğal kaynaktır; eksikliğinde bitkisel üretim, önemli ölçüde kısıtlanmaktadır (Kanber ve Ünlü, 2008: 2). Bilindiği gibi, kurak ve yarı kurak iklimlerde, bitki gelişimini sınırlandıran en önemli etmen, kök bölgesinde bulunan yarayışlı suyun eksikliğidir. Bu nedenle kurak ve yarı kurak alanlarda sulu tarım yapılması kaçınılmaz bir zorunluluk olarak karşımıza çıkmaktadır (Kanber ve Ünlü, 2008: 3). Nitekim bir bölgedeki yağış değerlerinin yeterli ve düzenli olmadığı, yani evapotranspirasyon (toprak yüzeyindeki buharlaşma, bitkilerdeki terleme) sonucu gerçekleşen su kayıplarının yağışlardan fazla olması durumunda, kültür bitkilerinin tarımının yapılabilmesi, ürün alınabilmesi için bitkilere gerekli suyun insanlar tarafından toprağa verilmesi gerekmekte ve bu olaya sulama denilmektedir (Bulut, 2006, s. 25).

Çalışma sahasında sulamalı tarım ile beraber pamuk ve mısır ekim alanları hızla artmıştır. Yetişme devresinde yüksek sıcaklık ve su isteyen bu iki bitkinin Kızıltepe'de yetiştirilmesi için gerekli olan sıcaklık değerleri yeterli iken ( en uygun $19{ }^{\circ} \mathrm{C}-25{ }^{\circ} \mathrm{C}$ arasında), suyun temin edilmesi ancak beşeri faaliyetler ile mümkündür. Yaz kuraklığının yüksek olduğu ilçede sulama yeraltından sondaj yolu ile sağlanmaktadır.

Mısır, çalışma sahasının en önemli tarımsal ürünü olarak karşımıza çıkmaktadır. Mısır üretiminde sulama-verim ilişkisi üzerine yapılan çalışmalarda, sulamanın üretimi önemli ölçüde etkilediği ortaya konulmuştur. Yapılan bu çalışmalarla, mısır bitkisinin ilk çiçeklenme (püskül çıkarma) döneminin su eksikliğine karşı çok duyarlı olduğu, belirlenmiştir. Örneğin, yağışın yıl boyunca türdeş dağılım gösterdiği Karadeniz Bölgesi'nin kıyı kesiminde yer alan Samsun'da, mısırda çiçeklenme döneminde yapılan sulamanın verime olumlu etki yaptığı saptanmıştır. Çalışma sahasının diğer önemli sanayi bitkisi olan pamuk, sulama esnasında yaklaşık \% 30 oranında su kısıtlaması uygulanmasına rağmen çok fazla randıman kaybetmediği belirlenmiştir. Belli oranda su kısıtlaması pamuk verimini pek etkilemezken sulama yönteminin pamuk bitkisinin su randımanını önemli oranda 
etkilemektedir. Örneğin damlama sulamada pamuk bitkisi suyu en randımanlı şekilde kullanmaktadır (Ünlü vd., 2008: 86). Su tüketimi, çimlenme döneminde düşük, gelişme ve olgunlaşma döneminde fazla olan pamukta (Korkmaz, 2009: 65) da misır üretiminde karşılaşın durumun benzeri yaşanmaktadır. Çalışma sahasında pamuğun gelişme ve olgunlaşma dönemlerinin Mayıs-Eylül ayları arasındaki dönemde gerçekleşmesi ve su ihtiyaçlarının yağışlarla karşılanamaması, Kızıltepe'de pamuk üretiminde sulamayı zorunlu kılmaktadır. Dolayısıyla Kızıltepe gibi evapotranspirasyon değerinin yüksekliğinden dolayı tuzlanma ve çoraklaşma riskinin olduğu alanlarda sulamanın mutlaka kontrollü şekilde yapılması gerekmektedir.

Benzer durum kuru tarım yöntemiyle yapılan buğday üretimi için de geçerlidir. Sulama imkânlarının geliştiği Kızıltepe'de sadece 2-4 kez sulama ile buğday üretiminde önemli bir artışın sağlandığı belirlenmiştir. İlk suyun ekimden hemen sonra, ekim ayı içerisinde verilmesi gerektiği; diğer sulamaların ise bahar aylarında, özellikle, ya kardeşlenme, çiçeklenme, sapa kalkma ya da süt olum dönemlerinde uygulanması önerilmiştir (Ünlü vd., 2008: 88). Nitekim Şanlıurfa'da sapa kalkma, başak çıkarma ve sütlenme dönemlerinde $3 \mathrm{kez}$ sulama yapılmış ve hektar başına $5070 \mathrm{~kg}$ verim alınmıştır. Buna karşılık Harran Ovası'nda buğdayın ekiminden hasadına kadar geçen sürede 5 kez sulama yapılmış ve hektar başına $7710 \mathrm{~kg}$ verim alınmıştır. Aslında Türkiye'de buğday verimi ile sulama arasında farklı bölgelerde farklı ilişkiler ortaya çıkmaktadır. Örneğin Tokat’ta buğdayın yetişme devresinde, yağış düşmesi sebebiyle sulama, buğday verimine pek etki yapmazken, buğdayın yetişme devresinde yağışın düşük olduğu Şanlıurfa'da, evapotranspirasyonun kısıtlanmasının buğday verimini olumsuz yönde etkileyeceği ve sulamanın yaşamsal önemde olduğu belirtilebilir (Ünlü vd., 2008: 91).

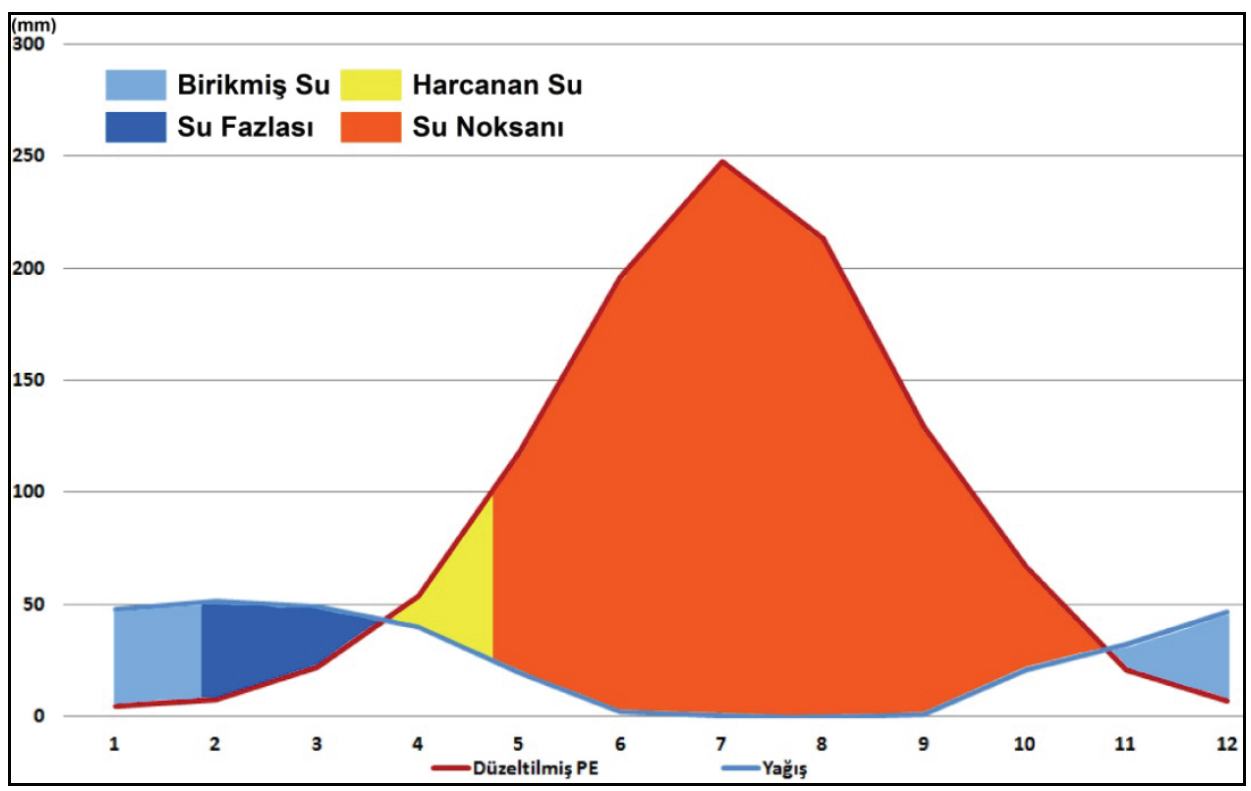

Şekil 18. Ceylanpınar istasyonunun Thornthwaite su bilançosu grafiği (Kızıltepe’ye yeryüzü şekilleri bakımından benzer ve mesafe olarak en yakın istasyon).

Yağış-sıcaklık-evapotranspirasyon ilişkisine dayanan Thornthwaite metodunda, yağışın evapotranspirasyondan fazla olduğu zamanlarda toprak suya doymuş haldedir. Bu durum su fazlas1 dönem olarak değerlendirilir ve nemli olarak kabul edilir. Buna karşl1ık yağışın evapotranspirasyondan sürekli az olduğu devrede, toprakta su bir türlü birikememekte, böylece toprakta su eksikliği ortaya çıkmaktadır ki, bu devre kurak devre olarak nitelendirilmektedir.

Çalışma sahasının Thornthwaite metoduna göre çizilmiş olan su bilançosu grafiğine göre sonbaharda başlayan yağışlarla beraber Kasım ayında toprakta su birikmeye başlamakta ve ancak kışın son ayı olan Şubatta toprakta su fazlalığı ortaya çıkmaktadır. Topraktaki fazla su Mart ayının 
sonundan itibaren hızla tüketilmeye başlanmakta ve Nisan ayının sonunda topraktaki fazla su tamamen bitmektedir. İlkbahar aylarındaki yüksek sıcaklıklar buharlaşmayı arttırmakta ve Mayıs ayı başından itibaren topraktaki su tamamen tüketmektedir. Yazın sıcak ve buna ek olarak kurak geçmesi, topraktaki su noksanı süresinin Ekim ayı sonuna kadar uzamasına neden olmaktadır (Şekil 18). Böylece ilkbaharın sonunda başlayan su noksanı sonbaharın başına kadar devam etmektedir. Dolayısıyla yetişme devresinde su ihtiyacı yüksek olan ürünlerin çalışma sahasında doğal şartlarda yetişmesi imkânsız gibidir.

Böylece Thornthwaite metoduna göre tespit edilen kurak ve nemli aylar ile tarım ürünlerinin yetişme devreleri karşılaştırıldığında sulamaya duyulan ihtiyaç ortaya konulabilmektedir. Buğdayın sonbaharda ekilmesi, buğdayın çimlenme ve gelişme dönemi olan Mart-Nisan aylarında ihtiyacı olan suyun büyük kısmını yağışlardan temin etmesini sağlar, böylece buğday şiddetli yaz kuraklığından etkilenmez. Dolayısıyla çalışma sahasında buğday üretiminde suya duyulan ihtiyaç düşük iken, özellikle kuraklığın en yüksek olduğu Temmuz ayında ekimi yapılan mısır, yaklaşık 4 ay boyunca suya ihtiyaç duymaktadır. Böylece çalışma sahasında mısır ekiminin yapılabilmesi ancak ve ancak sulama ile mümkün olmaktadır.

Kızıltepe ilçesinde sulama ile yetiştirilen mısır ve pamuğun net su ihtiyaçları ve su tüketim miktarlarına yönelik bir çalışma yapılmış değildir. Fakat Kızıltepe Ovası'nın devamı niteliğinde olan Ceylanpınar Ovası'nda bu bitkilerin net su tüketimleri ve su ihtiyaçları Tablo 4'deki gibidir. Buna göre Kızıltepe'de yaklaşık $400 \mathrm{~mm}$ civarında olduğu tahmin edilen yıllık toplam yağışların bu bitkilerin su ihtiyaçlarını karşılayamadığı kesindir. Nitekim pamuğun yıllık su tüketimi ile yıllık yağış değerleri arasında yaklaşık $700 \mathrm{~mm}$, mısırın su tüketimi ile yıllık yağış miktarı arasındaki fark ise yaklaşık $400 \mathrm{~mm}$ dir. Bu nedenle çalışma sahasında bu tür bitkilerin yetiştirilmesi yoğun bir sulamayı gerektirmektedir.

Çizelge 4. Kızıltepe'de sulama ile yetiştirilen ürünlerin su tüketimi ve su ihtiyaçları $\left(\mathrm{m}^{3} / \mathrm{da}\right.$. yıl). (Meteoroloji verilerinde olduğu gibi, Kızıltepe'de bitkilerin su ihtiyaçları ve su tüketimlerinin belirlenmesinde de Ceylanpınar ovasına ait veriler kullanılmışır).

\begin{tabular}{|l|c|c|}
\hline & Mısır II. Ürün & Pamuk \\
\hline Net su ihtiyacı (mm/yıl) & 623 & 791 \\
\hline Su tüketimi (mm/yıl) & 853 & 1084 \\
\hline
\end{tabular}

Kaynak: GAP Bölge Kalkınma İdaresi (2005, s.18-19).

Çalışma sahasında bu iki ürünün toplam su ihtiyacı, iki ürünün Tablo 3'de gösterilen ekim alanları dikkate alınarak hesaplamak mümkündür. Bu iki bitkinin 2010 yılındaki ekim alanları dikkate alındığında (mısır için 180 milyon $\mathrm{m}^{3} / \mathrm{da}$. yıl, pamuk için 106 milyon $\mathrm{m}^{3} / \mathrm{da}$. yıl su tüketilmektedir) yaklaşık 285-290 milyon m³/da. yıl su tükettikleri hesaplanmaktadır. Kızıltepe'de bu iki bitkinin y1llık su tüketimi ekim alanının yıllara göre genişlemesi veya daralmasıyla değişmektedir. 2009 yılında bu iki bitkinin ekim alanlarının genişlemesiyle su tüketimleri yıllık 325 milyon m³/da, 2008 yılında 346 milyon $\mathrm{m}^{3} / \mathrm{da}$. yıl olarak hesaplanabilir. Nitekim yapılan bir çalı̧̧mada Kızıltepe ovasında yıllık yer altı suyu işletme miktarı 350 milyon $\mathrm{m}^{3} / \mathrm{y}$ ll olarak belirtilmiştir (Kırmızıtaş, 2010: 1). Adı geçen çalışmada her ne kadar bitkilerin su tüketimleri göz önüne alınmamış olsa da yaptığımız hesaplamalarla büyük oranda örtüşmektedir.

\subsection{Tarımsal Üretimde Ortaya Çıkabilecek Olası Sorunlar}

Günümüzde sulu tarım sayesinde çiftçiler daha fazla gelir elde etmektedir. Fakat sulamalı tarıma alışı olmayan çiftçilerin suyu bilinçsizce kullanmaları ve tarım tekniklerini yeterince bilmemeleri ileride önemli sorunlara neden olabilir. Nitekim Karapınar ve çevresinde yapılan bir çalışmada bilinçsiz sulama ve yanlış tarım teknikleri nedeniyle tarım arazilerinde tuzlanma, çoraklaşma ve aşırı verim düşüklüğü gibi önemli sorunlar belirmiştir (Yılmaz, 2010: 152). Çalışma 
sahasının hemen batısında kalan Harran ovasında da yapılan benzer bir çalışmada, 1995-2003 yılları arasında yaklaşık 120.000 hektar alanın sulamalı tarıma açıldığı ve 2005 'te ovada yaklaşık 30.000 (toprakların \% 25'e yakını) hektar tarım alanının tuzlanıp, üretim ve kullanım dışı kaldığı tespit edilmiştir (Yenmez, 2005: 202). Su kullanımındaki artış, sadece Türkiye'de değil dünya genelinde çok önemli sorunlara neden olmaktadır. Nitekim aşırı su kullanım nedeniyle dünya genelinde yer altı su kaynakları tükenmekte, diğer su ekosistemleri kirlenmekte ve bozulmakta; ayrıca sulu tarımda birçok çevresel sorun ortaya çıkmaktadır. FAO'nun yürüttüğü çalışmaların kestirimlerine göre, sulanan alanların yaklaşık yarısı "sessiz düşman" olan tuzluluk, alkalilik ve yüzeyde göllenme tehdidi altındadır (Kanber ve Ünlü, 2008: 4).

Yukarıda değinilen, fakat şu anda çalışma sahasında ciddi olarak ortaya çıkmamış olan bu sorunlar, çiftçilerin toprak etütlerini yapmamaları, drenaj sorununu sulamanın bir parçası olarak görmemeleri, seçilen ürünlerin su ihtiyaçları tespit edilmeden sulamaları, sulama tekniklerinin yetersiz oluşu, topografya ve iklim gibi şartların göz ardı edilmesi gibi nedenlerle ileride sorun yaratacak boyuta ulaşacaklardır. Bu nedenle Kızıltepe'de oluşabilecek bu tür sorunlara yönelik çalışmalar hızlandırılmalıdır. Özellikle küresel 1sınmaya bağlı olarak son yüzyılda ortalama sıcaklıkların $0,4-0,8$ ${ }^{\circ} \mathrm{C}$ arasında artması (Türkeş, 2008: 1), yağışların sağanaklara dönüşmesi ve azalması, dünya nüfusunun giderek artması ve gıda sorununun sulamalı tarım ile çözülmeye çalışılması suyun ve toprağın önemini daha da arttırmaktadır. Şüphesiz suyun önemi Kızıltepe gibi yarı kurak iklim şartlarının hâkim olduğu alanlarda kendini daha çok hissettirmektedir. Kaldı ki arazi kullanımındaki değişimlerle beraber suya ihtiyaç duyan yeni ürünlerin seçilmesi kurak mevsimin hâkim olduğu alanlarda daha büyük risk oluşturmaktadır.

Çalışma sahasında sulama faaliyetlerinin tamamına yakını salma sulama şeklinde, bilinçsizce yapılmaktadır. Özellikle buharlaşmanın en yüksek olduğu Temmuz ve Ağustos aylarında mısır ve pamuk gibi ürünlerin üretiminde sulamanın yapıllyor olması, fakat toprağı drene edecek herhangi bir uygulamanın olmaması, toprakta tuzlanma riskini yükseltmektedir. Temmuz ve ağustos aylarında, gün ortasında sıcaklıkların $35^{\circ}{ }^{\circ}$ 'nin üzerine çıktığı Kızıltepe'de salma sulamanın çok büyük risk oluşturacağ açıkça ortadadır.

Günümüzde tarımsal üretimden iyi kazanç elde eden çiftçiler, sondaj maliyetine ek olarak farklı maliyetlerden kaçınmaktadır. Aslında çiftçiler birçok tarım tekniğinden haberdar olmakla beraber bu tür çalışmalara ilgisiz kalmaktadır. Özellikle sermaye gerektiren damla sulama sistemi yok denecek kadar azdır. Her ne kadar traktör, biçerdöver gibi tarımsal makinelerin kullanımı gün geçtikçe artıyorsa da, toprak ve su kaynakları ile ilgili her hangi bir önlem alınmadığını söyleyebiliriz.

Kızıltepe'de düşük yağış değerleri ve yüksek buharlaşma nedeniyle yüzeysel akışa geçen su yok denecek kadar azdır. Çalışma sahasında yüzeysel akışa geçen geniş bir akarsu ağı, doğal veya baraj göllerinin bulunmaması, tüm su ihtiyaçlarının yer altı suyundan karşılanmasını zorunlu kılmıştır. Kısıtlı yer altı suyu su rezervine sahip Kızıltepe'de, sulu tarım sahalarının gün geçtikçe genişlemesi ve bugünkü kullanımının yıllık kullanılabilir su rezervine yakın miktarda olması, yer altı suyunun tüketimini hızlandırmakta ve akiferlerdeki su miktarının gün geçtikçe düşmesine neden olmaktadır.

\section{Sonuç}

Arazinin kullanım kabiliyeti, erozyon, eğim, toprağın sığlığı ve derinliği yanında GAP (Güneydoğu Anadolu Projesi) kapsamında olması ve önemli miktarda yer altı suyu rezervine sahip olması gibi faktörler göz önüne alındığında Kızıltepe'nin Türkiye'nin önemli tarımsal potansiyele sahip yörelerden biri olduğunu söyleyebiliriz. Nitekim bu potansiyel günümüzde sulu tarım ile beraber yavaş yavaş tarımsal üretime de yansımış durumdadır.

Kızıltepe'de sulamalı tarım ile beraber bitki ekim alanlarının gün geçtikçe yüksek gelir getiren pamuk ve mısır gibi bitkiler lehine genişlediği görülmektedir. Bunun yanında özellikle mısır ve buğdayın rotasyonla ekilebiliyor olması, mısır ekim alanlarının daha hızlı genişlemesine sebep olmuştur. Nitekim Landsat uydu görüntülerine yansıyan verilere göre, 2000 yılının Ağustos ayında \% 
13 civarında olan sulu tarım alanları, 2010 yılının Ağustos ayında \% 44 seviyelerine yükselmiştir. Kısıtlı bir su rezervine sahip olan Kızıltepe'de, yaz kuraklığının uzun ve buharlaşmanın yüksek oluşu ileride erozyon, tuzlanma, çoraklaşma ve kalsifikasyon gibi tarımsal kökenli sorunların gelişebileceğine işarettir. Özellikle ürünlerin ekim zamanları ile yağış ve sıcaklığın aylara göre dağılımları incelendiğinde; buğday hariç diğer ürünlerin büyük oranda kuraklığın yaşandığı dönemde üretildiği görülmektedir. Haziran-Eylül ayaları arasındaki kritik dönemde sadece $3 \mathrm{~mm}$ civarında yağışın düştüğü çalışma sahasında, sıcaklık değerleri ise $25^{\circ} \mathrm{C}$ 'nin üzerindedir. Aynı dönemde bol su isteyen pamuk ve mısır ekimi yapılmakta ve bu iki ürünün de yetişme ve olgunlaşma zamanları sıcaklığın yüksek, yağışların düşük olduğu Haziran-Eylül dönemine denk gelmektedir. Sonuçta tarımsal üretimin yoğun olduğu dönem ile yağışın düşük ve sıcaklığın yüksek olduğu dönemler çakışmakta ve böylece sulamada suya duyulan ihtiyaç çok daha fazla olmaktadır.

$\mathrm{Su}$ kaynaklarının yetersiz olduğu günümüzde, kısıntılı sulama tekniği, uygulanabilir bir seçenek olarak kabul edilebilir. Bitkilerin su verim ilişkileri dikkate alınarak bitkinin suya hassas olmadığı dönemlerde sulama yapılmaması veya daha az su verilmesiyle uygulanan kısintılı sulama tekniğiyle, su artırımı sağlanabilmekte ve mevcut suyla daha fazla alanda sulama yapılabilmektedir. Örneğin Kızıltepe'de gün ortasında sıcaklıkların çok yüksek olması sebebiyle, sicaklığın $5-10{ }^{\circ} \mathrm{C}$ düştüğü akşamüzeri sulama yapılması en azından buharlaşma miktarı üzerinde etkili olacak ve doğru hesaplandığında sudan da tasarruf edilebilecektir. Dolayısıyla çiftçinin bilinçlendirilmesi ve uygun tarım tekniklerini kullanması yönünde uygulamalar ve çalışmalar yürütmek gerekmektedir. Bunlara ek olarak özellikle bilinçli sulama yapılıp, (bitkinin isteği kadar su verilmesi) toprakta biriken elementleri atacak ve fazla suyu drene edecek sistemler kullanılırsa toprakta tuzlanma riski büyük oranda azaltılacaktır.

\section{Referanslar}

Atalay, İ. (2006) Toprak Oluşumu, sınıflandırması ve Coğrafyası, Meta Basım Yayıncılık, İzmir.

Balcı Akova, S. (2002) Ergene Havzasının Coğrafi Potansiyeli, Çantay Kitabevi, İstanbul.

Bulut, İ. (2006) Genel Tarım Bilgileri ve Tarımın Coğrafi Esasları (Ziraat Coğrafyası), Gündüz Eğitim ve Yayıncılık. Ankara.

Doğanay, H. (2007) Ekonomik coğrafya 3: Ziraat Coğrafyası, Aktif Yayınevi, Erzurum.

Doğanay, H. (2011) Türkiye Ekonomik Coğrafyası, Pegem Akademi, Ankara.

Gap. (2011, 09 25). http://www.gap.gov.tr. 09 25, 2011 tarihinde http://www.gap.gov.tr/gap-eylem-plani/projeler/sulamaproje-listesi adresinden alınd

Gimpel, J. (2005) Ortaçağda Endüstri Devrimi, TÜBİTAK Yayınları, Ankara.

Kanber, R.; Ünlü, M. (2008) Türkiye'de Sulama ve Drenaj Sorunları: Genel Bakış, 5. Dünya Su Forumu Bölgesel Hazırlık Süreci DSI Yurtiçi Bölgesel Su Toplantıları Sulama-Drenaj Konferansı 10-11 Nisan (s. 1-45), Çevre ve Orman Bakanlığı Devlet Su İșleri Genel Müdürlüğü DSİ VI. Bölge Müdürlüğü, Adana.

Kantarc1, M. D. (2000) Toprak İlmi, İstanbul Üniversitesi Orman Fakültesi Yayınları, İstanbul.

Kırmızıtaş, H. (2010) Türkiye'de Sinıraşan Yeraltısuyu Rezervleri ve Kullanımı, Topraksu, Ankara.

Korkmaz, H. (2009) Amik Ovası'nda Kurak Devre ile Buğday, Pamuk ve Mısır Tarımı Arasındaki İlişki, Mustafa Kemal Üniversitesi Sosyal Bilimler Enstitüsü Dergisi , 6 (11), 56-68.

Lowdermilk, W. C. (2009) Toprağın 7000 Yıllık Öyküsü, Tema Vakfı Yayını, İstanbul.

Montogomery, D. R. (2010) Toprak: Uygarlıkların Erozyonu, Türkiye İş Bankası Kültür Yayınları, İstanbul.

Özçağlar, A. (1988) Türkiye'deki Tarım Alanlarının Coğrafi Dağılıșı, Coğrafya Araștırmaları Dergisi, 11, 131-150.

Sönmez, M. E. (2011) Uygarlıkların Çöküşünü Hazırlayan Hatalı Arazi Kullanımı, Toprak Erozyonunun Tarihsel Gelişimi Ve Güneydoğu Anadolu Bölgesi’ndeki Yansımaları. Gap VI. Tarım Kongresi, (s. 714-719). Şanlıurfa.

$\begin{array}{lllll}\text { Topraksu.(2012.04.11). } & \text { http://topraksuenerji.org.11 } & 04, & 2012 & \text { tarihinde }\end{array}$ http://topraksuenerji.org/haberler/sulama/GAP_Sulamalari_ve_Enerji.pdf adresinden alınd1

Tuik. (2000) 2000 Genel Nüfus Sayımı Nüfusun Sosyal ve Ekonomik nitelikleri, Türkiye İstatistik Kurumu Yayını, Ankara.

Tuik. (2011, 02 02). http://www.tuik.gov.tr. 02 02, 2011 tarihinde http://www.tuik.gov.tr/VeriBilgi.do?tb_id=37\&ust_id=11 adresinden alınd.

Tümertekin, E.; Özgüç, N. (1997) Beşeri Coğrafya İnsan -Kültür-Mekan, Çantay Kitabevi, İstanbul.

Tümertekin, E., \& Özgüç, N. (2009) Ekonomik Coğrafya Küreselleşme ve Kalkınma, Çantay Kitabevi, İstanbul.

Türkeş, M. (2008) İklim Değişikliği, Kuraklık, Çölleşme Süreçleri ve Tarıma Etkileri, Kuraklık ve Türkiye Tarımı (s. 1-41) içinde, Tema Vakfi Yayınları, İstanbul. 
62 Klzlltepe İlçesinde Bitkisel Ürün Deseninde Meydana Gelen Değişimler ve...

Ünlü, M.; Kanber, R.; Kapur, B.; Koç, D. L.; Tekin, S. (2008) Tarımsal Sulamada Su Artırımı: Kısıntılı Sulama Yaklaşımı, 5. Dünya Su Forumu Bölgesel Hazırlık Süreci Dsi Yurtiçi Bölgesel Su Toplantıları Sulama-Drenaj Konferansı 10-11 Nisan (s. 81-95), Çevre ve Orman Bakanlığı Devlet Su İşleri Genel Müdürlüğü DSİ VI. Bölge Müdürlüğü, Adana.

Yenmez, N. (2005) Ova Topraklarının Tuzlanmasına Yeni bir Örnek: Harran Ovası. Balıkesir Üniversitesi Sosyal Bilimler Dergisi , 8 (14), 199-236.

Yılmaz, M. (2010) Karapınar Çevresinde Yeraltı Suyu Seviye Değişimlerinin Yaratmış Olduğu Çevre Sorunları. Ankara Üniversitesi Çevre Bilimleri Dergisi , 2 (2), 145-163. 